\title{
The Modern Class Action Rule: Its Civil Rights Roots and Relevance Today
}

\author{
Suzette M. Malveaux*
}

\section{INTRODUCTION}

It is a golden anniversary. The modern class action rule ${ }^{1}$ recently turned fifty years old. However, the occasion is marred by troubled times. Hate crimes, violence and discrimination on the basis of race, religion, gender, immigration status, sexual orientation and more are on the rise. ${ }^{2}$ Prejudice that lay dormant has recently erupted, unleashing unbridled resentment, fury and even hatred. ${ }^{3}$ This spike has been particularly acute

* Professor of Law, Columbus School of Law, The Catholic University of America. Thank you to the Kansas Law Review for inviting me to present at its 2016 " 50 th Anniversary Perspectives on the Modern Class Action” Symposium and to publish with its journal. I appreciated the synergy of our panel so much that I brought us back together at the 2017 Southeastern Association of Law Schools (SEALS) Conference, which furthered my thinking on this topic. I also want to thank the faculty at the University of Iowa College of Law and the University of Denver Sturm College of Law for their insightful critiques and questions. I owe a debt of gratitude for the feedback of my students and the hard work of my research assistants (especially Sarah Mysiewicz for her excellent archival research). Finally, I continue to be grateful for and inspired by my parents whose tenacity, spirit and love guide me in my journey.

1. Throughout this article, the modern class action rule refers to Rule 23 of the Federal Rules of Civil Procedure, amended in 1966. See Fed. R. Civ. P. 23.

2. African-Americans, women, LGBT persons, immigrants and Muslims are being targeted in record numbers. The latest FBI annual report-admittedly a conservative estimate because of underreporting - reveals a six percent increase in bias-motivated criminal and related offenses. See Latest Hate Crime Statistics Released; Annual Report Sheds Light on Serious Issue, FBI: UCR (Nov. 14, 2016), https://www.fbi.gov/news/stories/2015-hate-crime-statistics-released ("This year's report, which contains data from 14,997 law enforcement agencies, reveals 5,850 criminal incidents and 6,885 related offenses that were motivated by bias against race, ethnicity, ancestry, religion, sexual orientation, disability, gender, and gender identity."); see also Ryan Gabrielson, Ryann Grochowski Jones \& Eric Sagara, Deadly Force, in Black and White, ProPuBlica (Oct. 10, 2014, 11:07 AM), https://www.propublica.org/article/deadly-force-in-black-and-white (citing FBI reports of 1,217 deadly police shootings from 2010 to 2012 that shows "young black men are 21 times as likely as their white peers to be killed by police"); Omar Villafranca, Muslims in U.S. Report Spike in Discrimination, Threats, CBS NEwS (Dec. 7, 2015, 7:35 PM), http://www.cbsnews.com/ news/muslims-in-u-s-report-spike-in-discrimination-threats/ (reporting accounts of discrimination against Muslims in America).

3. Some project that this trend will continue. See, e.g., CTR. FOR THE STUdY OF HATE \& Extremism, Cal. State UniV., San Bernardino, Final U.S. Status Report Hate Crime ANALYSIS \& FORECAST FOR 2016/2017 1-3 (2017), https://csbs.csusb.edu/sites/csusb_csbs/files /Final\%20Hate\%20Crime\%2017\%20Status\%20Report\%20pdf.pdf (forecasting an increase in hate crimes for the five largest American cities in 2017). 
following the presidential election of Donald Trump. ${ }^{4}$ Official government policies and rhetoric have also taken a punitive turn. ${ }^{5}$ In response, activism for racial justice, gender equality and civil and human rights has exploded, as exemplified by the Black Lives Matter movement, ${ }^{6}$ the National Women's March $^{7}$ and the Dreamers initiative, ${ }^{8}$ among

4. See Hate Groups Increase for Second Consecutive Year as Trump Electrifies Radical Right, S. POVERTY LAW CTR. (Feb. 15, 2017), https://www.splcenter.org/news/2017/02/15/hate-groupsincrease-second-consecutive-year-trump-electrifies-radical-right (finding "[t]he most dramatic growth was the near-tripling of anti-Muslim hate groups" and "the number of hate groups operating in 2016 rose to 917-up from 892 in 2015. The number is 101 shy of the all-time record set in 2011, but high by historic standards."); see, e.g., Over 200 Incidents of Hateful Harassment and Intimidation Since Election Day, S. POVERTY LAW CTR. HATEWATCH (Nov. 11, 2016), https://www.splcenter.org/ hatewatch/2016/11/11/over-200-incidents-hateful-harassment-and-intimidation-election-day

(reporting nation-wide intimidation and harassment against Blacks, women, LGBT, immigrants and Muslims, and noting that "[o]ften times, ... many incidents, though not all, involved direct references to the Trump campaign"); Violence Against the Transgender Community in 2017, HUM. RTS. CAMPAIGN, http://www.hrc.org/resources/violence-against-the-transgender-community-in-2017 ("In 2016, advocates tracked at least 23 deaths of transgender people in the United States due to fatal violence, the most ever recorded."); Sangay K. Mishra, An Indian Immigrant is Murdered in Kansas. It's Part of a Spike in Hate Crimes Against South Asians, WASH. Post (March 7, 2017), https://www.washingtonpost.com/news/monkey-cage/wp/2017/03/07/the-kansas-murder-of-anindian-immigrant-is-part-of-a-spike-in-hate-crimes-against-south-asians/?utm_term=.699d6b03953f (documenting a 34 percent increase in "hate violence and xenophobic political rhetoric targeting South Asian, Muslim, Sikh, Hindu, Middle Eastern and Arab communities in the year leading up to the 2016 elections"); Press Release, Human Rights Campaign, Groundbreaking Survey of 50,000+ Young People Reveals Troubling Post-Election Spike in Bullying (Jan. 18, 2017), http://www.hrc.org/press/groundbreaking-survey-of-50000-young-people-reveals-troubling-post-

election ("Seventy percent of respondents reported witnessing bullying, hate messages or harassment during or since the 2016 election. Of those, [seventy-nine] percent said such behaviors have been occurring more frequently since the onset of the presidential campaign.”).

5. See Juliet Eilperin, Emma Brown, \& Darryl Fears, Trump Administration Plans to Minimize Civil Rights Efforts in Agencies, WASH. POST (May 29, 2017), https://www.washingtonpost.com/ politics/trump-administration-plans-to-minimize-civil-rights-efforts-in-agencies/2017/05/29/ 922fc1b2-39a7-11e7-a058-ddbb23c75d82 story.html?utm term=.2cbc8e1c9d97; Dona Owens, 100 Days of Civil Rights in the Trump Administration, NBC News (Apr. 29, 2017 9:17 AM), https://www.nbcnews.com/storyline/president-trumps-first-100-days/100-days-civil-rights-trumpadministration-n752536; Graham Vyse, Donald Trump's War on Civil Rights Is Intensifying, NEW REPUBLIC (May 20, 2017), https://newrepublic.com/minutes/142951/donald-trumps-war-civil-rightsintensifying.

6. See About the Black Lives Matter Network, BLACK LiVES MATTER, https://blacklivesmatter.com/about/ (last visited Dec. 11, 2017); see also Elizabeth Day, \#BlackLivesMatter: The Birth of a New Civil Rights Movement, GuARDIAN (July 19, 2015), https://www.theguardian.com/world/2015/jul/19/blacklivesmatter-birth-civil-rights-movement ("Black America is in a state of protest. The 21 st-century civil rights movement, exemplified by the action taken by Garza and those like her, is democratic in its aims and agile in its responses. It is fueled by grief and fury, by righteous rage against injustice and institutionalized racism and by frustration at the endemic brutality of the state against those it deems unworthy.").

7. See WOMEN'S MARCH ON WASHINGTON, https://www.womensmarch.com (last visited Dec. 11, 2017); Emily Barasch, A Brief History of the Women's March on Washington, COVETEUR (Feb. 24, 2017), http://coveteur.com/2017/01/18/brief-history-womens-march-washington/.

8. The Deferred Action for Childhood Arrivals (DACA), initiated by the Obama Administration, provided temporary protection from deportation and other opportunities to 
others. ${ }^{9}$

There is a peculiar irony in the fact that this modern federal class action rule ${ }^{10}$ marks its golden anniversary within a similarly tumultuous environment as its birth. ${ }^{11}$ The rule itself is rooted in the turbulent history of the civil rights movement of the 1960s and was designed to enhance civil rights enforcement. ${ }^{12}$ In response to fierce resistance to desegregation following the iconic 1954 Brown v. Board of Education decision, the rule drafters amended Rule 23 in 1966 to enable structural reform and broad remedial relief. ${ }^{13}$ Since then, this aggregation device has played a seminal role in the private enforcement of statutory and Constitutional civil rights.

undocumented immigrants who came to the United States as children (i.e., "Dreamers"). President Trump's recent decision to end the program has result in protests nationwide. Noah Lanard, Nationwide Protests Hit the Streets After Trump Decision to End Dreamer Protections, MOTHER JONES (Sept. 5, 2017), http://www.motherjones.com/politics/2017/09/nationwide-protests-hit-thestreets-after-trump-decision-to-end-dreamer-protections/.

9. See John Bacon \& Alan Gomez, Protests Against Trump's Immigration Plan Rolling in More than 30 Cities, USA TODAY (Jan. 29, 2017, 7:52 PM), http://www.usatoday.com/ story/news/nation/2017/01/29/homeland-security-judges-stay-has-little-impact-travel-ban/97211720; Amber Jamieson, After the Women's March: Six Mass US Demonstrations to Join this Spring, THE GUARDIAN (Feb. 5, 2017, 10:33 AM), https://www.theguardian.com/world/2017/feb/05/womensmarch-mass-protests-scientists-immigrants-climate-change.

10. FED. R. CIV. P. 23(b)(2). This paper focuses on this specific provision of the 1966 modern class action rule.

11. The civil rights movement of the 1960s involved massive non-violent protests and efforts to integrate schools, lunch counters, transportation and public accommodations, to acquire voting rights, and to economically empower communities. Freedom riders, activists, and organizers faced church bombings, mob violence, and terrorism by the KKK and others. For a history of the civil rights movement, see generally Eyes on the Prize: Awakenings (1954-1956) (PBS Television broadcast January 21, 1987); Eyes on the Prize: Fighting Back (1957-1962) (PBS Television broadcast January 28, 1987); HENRY HAMPTON \& STEVE FAYER, VOICES OF FrEEDOM: AN ORAL HiSTORY OF THE CIVIL Rights MOVEMENT FROM THE 1950S THROUGH THE 1980S (1991) (companion book to Eyes on the Prize).

12. See infra Part IB. See also Arthur R. Miller, Simplified Pleading, Meaningful Days in Court, and Trials on the Merits: Reflections on the Deformation of Federal Procedure, 88 N.Y.U. L. REV. 286, 315 (2013) (Rule 23's 1966 revision meant to "provide a useful procedural vehicle, particularly for civil rights"); Arthur R. Miller, Some Very Personal Reflections on the Rules, Rulemaking, and Reporters, 46 U. MICH. J. L. REFORM 651, 652-53 (2013); see also generally Robert G. Bone, Walking the Class Action Maze: Toward a More Functional Rule 23, 46 U. Mich. J. L. Reform 1097, 110206 (2013) (describing the history of the 1966 amendments to Rule 23).

13. Brown v. Bd. of Educ., 347 U.S. 483 (1954); David Marcus, Flawed but Noble: Desegregation Litigation and Its Implications for the Modern Class Action, 63 FLA. L. REV. 657, 695700 (2011) [hereinafter Marcus, Flawed but Noble]; see also RisA L. GolubOFF, THE Lost PROMISE OF Civil Rights, in CiVIL RightS StORIES 25, 25-26 (2008) (“[Brown] radicalized southern whites to resist (sometimes violently) the changes the Supreme Court's decision set in motion."); id. at 31 (describing "white opposition to such desegregation [as] passionate and unyielding"); $i d$. at 26-27 (describing how civil rights lawyers challenged 75 year old "racial and economic caste system" and how "violence and legal chicanery" in the south "made it possible to inscribe Jim Crow into legal and political structures for generations"). 
The rule's rich history makes clear that the drafters infused this procedural mechanism with the capacity of being used to challenge racial inequality and subordination. ${ }^{14}$ A half-century since its inception, Rule 23(b)(2) remains unchanged. And, like at the modern rule's birth, America's civil rights climate is in turmoil. The unmasked vitriol and prejudice against religious, ethnic and racial minorities, among others, and the rebirth of activism to counteract this trend harkens back to the nadir of the modern class action rule. ${ }^{15}$ The time is ripe, therefore, to determine whether this critical aggregation device is functioning as intended.

This article proceeds as follows. Part I describes the historical background of the modern class action rule in relation to civil rights. More specifically, this Part reveals how the drafters deliberately crafted the rule to address desegregation obstructionism. Part II analyzes Supreme Court jurisprudence interpreting Rule 23(b)(2) over the course of the last fifty years, identifying three primary periods in which the pendulum has swung: from a heyday of liberal class certification for broad injunctive relief for newly created rights; to a heightened critique and retraction of class certification; to a complex gauntlet of contemporary barriers involving evidentiary hurdles, contractual restrictions and access limitations. Part III critiques modern class action jurisprudence and concludes that it fails to sufficiently fulfill the drafters' intent of creating an efficient and just procedural mechanism for pursuing systemic racial equality. The Article recommends a contemporary judicial interpretation more anchored to the bone, rooted in Rule 23(b)(2)'s strong civil rights mission.

\section{THE MODERn Class ACTION RULE's HistoriCAL GROUNDING IN CIVIL RIGHTS}

\section{A. The Pre-Cursor to the Modern Class Action Rule-An Equitable Tool for Civil Rights Enforcement}

The American class action rule was born in 1938 with the goal of promoting equity and access. ${ }^{16}$ Indeed, from 1938 to 1966 , the rule

\footnotetext{
14. See infra Part II. Unsurprisingly, the drafters primary target at the time was segregation, whose pernicious existence long post-dated Brown v. Board of Education, 347 U.S. 483 (1954).

15. See John Wagner \& Scott Clement, 'It's Just Messed Up': Most Think Political Divisions as Bad as Vietnam Era, New Poll Shows, WASH. POST (Oct. 28, 2017), https://www.washingtonpost.com/graphics/2017/national/democracy-poll/?tid=a_in1\&utm_term=.f8 6 cfde801fa ("Seven in 10 Americans say the nation's political divisions are at least as big as during the Vietnam War").

16. 7A Charles Alan Wright et al., Federal Practice \& Procedure $\S 1752$, at 18 (3d ed. 2005).
} 
provided, inter alia, a mechanism for those fighting racial oppression to act collectively. Following the 1954 seminal Brown v. Board of Education decision-holding segregated public schools unconstitutional-the aggregation rule was tapped for stemming systemic discrimination and segregation in various areas including employment, education, public accommodations and housing. ${ }^{17}$

The aggregation rule, however, required litigants to shoehorn their case into one of three jural relations: "true," "hybrid" or "spurious." In a nutshell: "true" classes involved joint or common rights; "hybrid" classes involved several rights concerning a claim over a specific property; and "spurious" classes involved several rights, with only a common question and common relief justifying aggregation. ${ }^{18}$ Numerosity ${ }^{19}$ and adequacy of representation ${ }^{20}$ - principles required from the rule's inception ${ }^{21}$ - were often satisfied for "race relations" civil rights cases from the late 1930s to $1960 \mathrm{~s}^{22}$ Within this three-tiered structure, civil rights cases were housed in the "true" and "spurious" classes. For example, union members could challenge racial discrimination in a collective bargaining agreement as a "true" class because of their joint or common rights. ${ }^{23}$ By contrast, individual litigants challenging segregated facilities as unconstitutional often constituted a "spurious" class because of their "several" rights. ${ }^{24}$

Prior to 1966 , most civil rights cases were technically classified as "spurious.", Although class members sought "common relief," and shared a "common question of law or fact," each class member was the sole owner of his or her rights. ${ }^{26}$ Thus, in spurious suits, res judicata was

17. Brown v. Bd. of Educ., 347 U.S. 483 (1954); 7A WRIGHT, supra note 16, § 1752, at 22-25 \& nn.31-34 (listing cases).

18. 7A WRIGHT, supra note $16, \S 1752$ at $18,21,28-31$. These three classifications were set forth in then-Rule 23(a). "True" class actions also included a "secondary" right: i.e. "secondary in the sense that the owner of a primary right refuses to enforce that right and a member of the class thereby becomes entitled to enforce it." Id. § 1752, at 21-22.

19. See FED. R. CIV. P. 23(a)(1) (current) ("the class is so numerous that joinder of all members is impracticable").

20. See FED. R. CIV. P. 23(a)(4) (current) ("the representative parties will fairly and adequately protect the interests of the class").

21. 7A WRIGHT, supra note $16, \S 1752$, at 20.

22. See John P. Frank, Response to 1996 Circulation of Proposed Rule 23 on Class Actions, in 2 Working Papers of the Advisory COMM. ON Civil Rules on Proposed AMENDMENTS to CiviL RUle 23 260, 266 (Rules Committee Support Office, 1997), http://www.uscourts.gov/ sites/default/files/workingpapers-vol2.pdf.

23. 7A WRIGHT, supra note $16, \S 1752$, at $22-23 \&$ n.23 (citing cases).

24. Id. $\S 1752$, at 21-25 (noting connection between Rule 23(b)(2) class actions and the prior "spurious" actions, "particularly those involving civil rights" and citing cases).

25. Frank, supra note 22, at 672.

26. These were requirements of spurious classes. 7A WRIGHT, supra note 16, § 1752, at 30- 
available only for the named plaintiffs and class members who intervened. ${ }^{27}$ The nature of the rights pursued meant that such cases could be denied certification altogether or limited to only the parties involved. ${ }^{28}$

Many, perhaps most, judges certified desegregation cases regardless of the several rights at issue. ${ }^{29}$ While recognizing that individuals had their constitutional rights violated and were entitled to pursue their individual claims, many judges recognized race discrimination as inherently grouporiented and thus suited for class treatment. ${ }^{30}$ Moreover, many judges who certified civil rights cases as "spurious" classes did not worry about the limited res judicata implication of the label, concluding that injunctive relief curtailing racially discriminatory policies and laws would eventually apply more broadly even to non-parties. ${ }^{31}$

However, this approach was hardly uniform. The rule's malleability gave judges who opposed integration a sword with which to castrate Brown. Judges could, and did, as easily refuse to certify a class of AfricanAmericans challenging the constitutionality of segregation policies, on the grounds that such rights belonged to the individual. ${ }^{32}$ For those cases that were certified as "spurious" class actions, many judges applied desegregation orders only to the plaintiffs and against the particular defendant institutions before them. ${ }^{33}$ This conception of the spurious class's utility led some commentators to conclude: "If this is really all the 'spurious' class suit did, then there was very little justification for its existence." 34

31. They justified this type of class action because of the efficiency they offered. 7A WRIGHT, supra note $16, \S 1752$, at 30 .

27. Frank, supra note 22, at 673.

28. See David Marcus, The History of the Modern Class Action, Part I: Sturm Und Drang, 1953-1980, 90 WASH. U. L. REV. 587, 601 (2013) [hereinafter Marcus, History of the Modern Class Action]; 7A WRIGHT, supra note 16, § 1752, at 30-31.

29. Indeed, Committee Member Benjamin Kaplan noted "the very desegregation suits that are now [in 1963] being conducted are theoretically spurious class actions, but there isn't a judge in the world that's treating them that way, nor should they be treated that way." Transcript of Sessions on Class Actions-EE, Civil Rules Meeting Oct. 31-Nov. 2, 1963, in RECORDS OF THE U.S. JUDICIAL CONFERENCE: COMMitTeEs ON Rules OF PRACTICE AND PROCEDURES, 1935-1988 [hereinafter RECORDS OF THE U.S. JUDICIAL CONFERENCE], microformed on CIS No. CI-7104, 24, 41 (Cong. Info. Serv.); see also 7AA WRIGHT, supra note 16, § 1776, at 81-83 ("Prior to the 1966 amendment of Rule 23 most federal courts recognized that class actions were an appropriate means to vindicate an alleged denial of civil rights. Thus, although there was no specific provision in original Rule 23 comparable to present subdivision (b)(2), class actions were maintained challenging discrimination in employment, education, the use of public facilities, and housing.").

30. 7A WRIGHT, supra note $16, \S 1752$, at 26 .

31. Id. at 28 .

32. Id. at $23-26$.

33. See id. at 31 .

34. See id. at 31-32 (summarizing Second Circuit Judge Charles E. Clark's perception of the 
Thus, in revamping the class action rule in 1966, the drafters eliminated the "true," "hybrid" and "spurious" classifications, which conditioned the scope of the judgment's preclusive effect on the nature of rights pursued. ${ }^{35}$ These classifications proved unworkable, with many judges finding them confusing, applying them inconsistently or concluding that they were ultimately immaterial. ${ }^{36}$ The drafters moved away from jural relations, and crafted three different types of class actions unrelated to the former. ${ }^{37}$ The modern class action rule, revised in 1966, sets forth the three classes:

(b) Types of Class Actions. A class action may be maintained if Rule 23(a) is satisfied and if:

(1) prosecuting separate actions by or against individual class members would create a risk of:

(A) inconsistent or varying adjudications with respect to individual class members that would establish incompatible standards of conduct for the party opposing the class; or

(B) adjudications with respect to individual class members that, as a practical matter, would be dispositive of the interests of the other members not parties to the individual adjudications or would substantially impair or impede their ability to protect their interests;

(2) the party opposing the class has acted or refused to act on grounds that apply generally to the class, so that final injunctive relief or corresponding declaratory relief is appropriate respecting the class as a whole; or

(3) the court finds that the questions of law or fact common to class members predominate over any questions affecting only individual members, and that a class action is superior to other available methods for fairly and efficiently adjudicating the controversy.... ${ }^{38}$

To accomplish their goal of designing an aggregation rule that would empower those fighting for racial equality, the rule makers specifically

\footnotetext{
spurious class action as an invitation to others to join the litigation and warning to the judge to be mindful of the relief ordered because of its potential precedential effect on non-parties).

35. Id. at 21 .

36. Id. at $21-26$.

37. See id. at 21 (noting a "rough correspondence" but concluding that "the old categories do not and were not intended to coincide with the new").

38. FED. R. CIV. P. 23(b).
} 
drafted Rule 23(b)(2), ${ }^{39}$ permitting a class action to be maintained when a defendant has acted on grounds generally applicable to a group, justifying group-wide injunctive or declaratory relief. ${ }^{40}$ The Committee noted "[i]llustrative are various actions in the civil-rights field where a party is charged with discriminating unlawfully against a class, usually one whose members are incapable of specific enumeration."41 Although Rule 23(b)(2) is not limited to civil rights cases, its driving force and evolution stem from a commitment to systemic desegregation and racial equality. ${ }^{42}$

The (b)(2) designation eliminated a distinction some courts would make to justify prohibiting class treatment for civil rights cases. ${ }^{43}$ For example, in the Fifth Circuit, one judge granted class certification in a case where a registrar outright refused to deal with any African-Americans who wanted to register to vote. ${ }^{44}$ Another judge in the Fifth Circuit, however, denied class certification in a case where a registrar individually struck African-American voters from the rolls because of their race. ${ }^{45}$ Because the former challenged a policy discriminatory against a group on its face and the latter challenged the discriminatory application of a neutral policy to various individuals, different class treatment was justified. ${ }^{46}$ Rule 23(b)(2) makes this distinction irrelevant.

The (b)(2) provision provides court access to litigants who could not effectively seek injunctive relief on their own. ${ }^{47}$ As a tool of equity, the class action device cleared a way for individuals to wield more power to

39. 7AA WRIGHT, supra note $16, \S 1776$, at 83 ("'S] ubdivision (b)(2) was added to Rule 23 in 1966 in part to make it clear that civil-rights suits for injunctive or declaratory relief can be brought as class actions."); Jack Greenberg, Civil Rights Class Actions: Procedural Means of Obtaining Substance, 39 ARIZ. L. REV. 575, 577 (1997) ("The partnership between class actions and civil rights has grown to such an extent that the Advisory Committee revising Rule 23 noted that, 'subdivision (b)(2) has cemented the role of class actions in enforcing a wide array of civil rights claims."'); Benjamin Kaplan, Continuing Work of the Civil Committee: 1966 Amendments of the Federal Rules of Civil Procedure (I), 81 HARV. L. REV. 356, 389 (1967) (explaining that the "new subdivision (b)(2) [was built] on experience mainly, but not exclusively, in the civil rights field").

40. FED. R. CIV. P. 23(b)(2).

41. FED. R. CiV. P. 23(b)(2) advisory committee's notes to 1966 amendment (emphasis added).

42. See Marcus, Flawed but Noble, supra note 13, at 703-04; see Frank, supra note 22, at 267 ("Put at its simplest, what new Rule 23[(b)(2)] did . . . [was] make sure that suits against segregation, as well as other civil rights cases, would be within the class action rule and would be binding as to all members of the class liberally conceived ....")

43. 7A WRIGHT, supra note $16, \S 1752$, at 26-28 \& nn.37-40.

44. Sharp v. Lucky, 252 F.2d 910, 913 (5th Cir. 1958).

45. Reddix v. Lucky, 252 F.2d 930, 938 (5th Cir. 1958).

46. See 7A WRIGHT, supra note 16, § 1752, at 26-28 (recognizing the distinction). But see Note, Proposed Rule 23: Class Actions Reclassified, 51 VA. L. REV. 629, 647 n.57 (1965) (doubting the distinction).

47. See Max Helveston, Promoting Justice Through Public Interest Advocacy in Class Actions, 60 BUFF. L. REV. 749, 764 (2012). 
curb systemic misconduct through litigation. ${ }^{48}$

\section{B. Aggregation as a Force for Addressing Civil Rights Opposition}

The history of the modern class action rule, enacted in 1966, was intimately interwoven with that of the broader civil rights struggle of the time. ${ }^{49}$ As one of the drafters and Advisory Committee Members, John P. Frank, revealed:

If there was [a] single, undoubted goal of the [Advisory] [C]ommittee, the energizing force which motivated the whole rule, it was the firm determination to create a class action system which could deal with civil rights and, explicitly, segregation. The one part of the rule which was never doubted was (b)(2) and without its high utility, in the spirit of the times, we might well have had no rule at all.

The drafters of the modern class action rule worked before a backdrop of intransigence and fierce resistance to desegregation efforts, especially in the south. Following Brown's holding that the "separate but equal" doctrine in public schools was unconstitutional, southern backlash was severe. $^{51}$ Thus, when amending Rule 23 in 1966, the drafters were informed by and motivated to overcome obstructionist procedural barriers erected by legislative and judicial forces. ${ }^{52}$

State legislatures deliberately erected barriers, such as state pupil assignment laws to preserve segregated schools. ${ }^{53}$ In an effort to keep

48. Id. (noting that drafters of (b)(2) were unsurprisingly "motivated by equitable concerns"); $i d$. at 764-65 ("The expansion of class action access to ... litigants [challenging systemic civil rights violations and discrimination] constituted an attempt to make our procedural system more equitable by creating a means for individuals to bring injunction-based reform litigation.").

49. Marcus, Flawed but Noble, supra note 13, at 678-79.

50. See Frank, supra note 22, at 266.

51. Marcus, Flawed but Noble, supra note 13, at 692.

52. Justice Department Assistant Attorney General and 1963 Advisory Committee Member Louis Oberdorfer conceded the unpopularity of civil rights and labor cases at the time. In revising the class action rule, the drafters proposed Rule 23(a), which stated that "[o]ne or more members of a class may sue or be sued as representative parties on behalf of all only if [numerosity, commonality, typicality and adequacy were met]." Preliminary Draft of Proposed Amendments to Rules of Civil Procedure for the United States District Courts (Mar. 15, 1963), in RECORDS OF THE U.S. JUDICIAL CONFERENCE, supra note 29, microformed on CIS No. CI-8004, 2,3 (Cong. Info. Serv.) (emphasis added). Oberdorfer questioned whether the term "only" "might be overemphasized by courts to bar class actions in unpopular civil rights, labor, or other similar fields." Letter from Assistant Attorney General Louis Oberdorfer to Benjamin Kaplan (Feb. 12, 1963), in RECORDS OF THE U.S. JUdICIAL CONFERENCE, supra note 29, microformed on CIS No. CI-7001, 2, 3 (Cong. Info. Serv.).

53. Marcus, Flawed but Noble, supra note 13, at 684. As Columbia Professor of Law and former NAACP Legal Defense and Educational Lawyer Jack Greenberg recalls:

$[\mathrm{M}]$ ost southern states passed laws, known as pupil placement laws, which prescribed procedures for application and transfer by individual black children to white schools. 
schools de facto segregated following Brown, local school boards would individually assign students to schools according to race. ${ }^{54}$ Such boards purposefully manufactured individualized issues via pupil assignment laws, thereby making it difficult for African-American students to collectively act through class actions. ${ }^{55}$

For example, in Potts v. Flax, ${ }^{56}$ the Fort Worth Independent School District established a pupil assignment law post-Brown, in an attempt to preserve a segregated public school system. ${ }^{57}$ While admitting the existence and binding effect of Brown, the School Board nonetheless continued to maintain a seventy-eight-year-old segregated school system because of the Board's unabashed support of segregation. ${ }^{58}$ AfricanAmerican students challenged the pupil assignment law as unconstitutional and sought relief as a class action. ${ }^{59}$ The School Board balked at the district court judge's purported need to order the Board to implement its law in a non-discriminatory manner, arguing that an ad hoc approach was best. ${ }^{60}$ Based on "uncontradicted evidence," of the Board's "categorical[1] reaffirm[ance of] its adherence to the formal policy of a segregated system" the court left nothing to chance and issued an order abolishing the pupil assignment law and requiring a concrete desegregation plan. ${ }^{61}$

Alternatively, the School Board contended that even if the court had the authority to issue a desegregation order as to the individual plaintiffs, the court could not expand this to all those similarly situated. ${ }^{62}$ The Board maintained that because admission, assignment and transfer of AfricanAmerican students had to be done on an individualized basis under the pupil assignment law, a class action challenging the law was improper. ${ }^{63}$ Thus, the Board appealed the district court's certification of a class of African-American children challenging the School District's pupil assignment scheme as racially discriminatory. The Fifth Circuit affirmed

\footnotetext{
Although these transparently were stratagems for maintaining segregation, and although efforts to transfer routinely were frustrated, the courts, including the Supreme Court, for many years upheld the laws. 
class certification, concluding, inter alia:

The issue of law - may the School Board constitutionally assign Negro children to schools solely by reason of race? - was common to every Negro child in the Fort Worth District. ... [Moreover,] there was not the slightest suggestion either on the trial (or since) that within the large mass there was any substantial conflict either in interest or in the legal positions to be advanced. ${ }^{64}$

The Fifth Circuit rejected the Board's attempt to cast the case in terms of individual rights and remedies, and instead recognized the group-wide harm and appropriate group-wide relief: ${ }^{65}$

$[\mathrm{P}]$ erhaps most important, the relief to the class ... was a good deal more than something merely appropriate. There is at least considerable doubt that relief confined to individual specified Negro children either could be granted or, if granted, could be so limited in its operative effect. By the very nature of the controversy, the attack is on the unconstitutional practice of racial discrimination. Once that is found to exist, the Court must order that it be discontinued. ${ }^{66}$

To order something shy of this would be akin to court's outright endorsement of segregation: "[T] o require a school system to admit the specific successful plaintiff Negro child while others, having no such protection, were required to attend schools in a racially segregated system, would be for the court to contribute actively to the class discrimination proscribed. ${ }^{, 67}$

The Fifth Circuit goes so far to say that alternatively, even if the district court erred in certifying the class action and issuing class-wide relief, the error was harmless because the relief would have been

64. Id. at 289 .

65. Id. at 288-89 ("Properly construed the purpose of the suit was not to achieve specific assignment of specific children to any specific grade or school. The peculiar rights of specific individuals were not in controversy. It was directed at the system-wide policy of racial segregation. It sought obliteration of that policy of system-wide racial discrimination."); see also id. at 289 n.5 ("[A] school segregation suit presents more than a claim of invidious discrimination to individuals by reason of a universal policy of segregation. It involves a discrimination against a class as a class, and this is assuredly appropriate for class relief.") (emphasis added).

66. Id. at 288-90. Jack Greenberg makes a similar point, noting that the school desegregation cases focused on specific African-American students who sought transfer to specific white schools. The courts later recognized that Brown required more-i.e. an African-American child's right to an integrated public school system. This broader understanding of Brown's mandate meant that a single plaintiff could desegregate all of the schools in one lawsuit, regardless of its class action status. While aggregation would be appropriate, it would effectively be "surplusage." Greenberg, supra note 39, at 580-81.

67. Potts, 313 F.2d at 289. 
pragmatically speaking the same if limited to the named plaintiffs.

Potts illustrates not only the ways in which states attempted to obstruct Brown's desegregation mandate through pupil assignment laws, but also the ways in which judges countered such obstruction. By way of class certification, judges formally tailored the scope of relief to a relevant class to avoid the potential unfairness that could result from excluding nonparties in desegregation orders. Where such protection could not be perfected through the class action, it would be up to subsequent judges to determine the preclusive effect of the desegregation order.

Such discretion meant that judges sympathetic to segregation could easily undermine the scope and speed of compliance with Brown. ${ }^{68}$ Such judges denied certification of classes seeking to integrate public schools by relying on the largely theoretical possibility that class members' interests might diverge, ${ }^{69}$ or that only individuals could assert their rights under the Fourteenth Amendment. ${ }^{70}$

Another example of this phenomenon at the time is Brunson v. Board of Trustees. ${ }^{71}$ Like Potts, forty-two African-American school children challenged the Clarendon County School District for operating a racially segregated school system post-Brown. ${ }^{72}$ Like many southern states, ${ }^{73}$ South Carolina had enacted a pupil placement statute, giving the School Board the power to decide whether a student could transfer from his or her assigned school to another one of the student's choice. ${ }^{74}$

The students brought the case as a "spurious" class action on account that each student had his or her own right. ${ }^{75}$ The district court struck the class allegations in the complaint challenging the county's segregated

68. See 7A WRIGHT, supra note 16, § 1752, at 23-24 ("Questions relating to the availability of class actions in matters involving racial discrimination led to some difficulty.").

69. Id. $\S 1752$, at $26 \mathrm{n} .35$ ("The holdings . . . that actions to end segregation were not proper class actions because some Negroes favored these suits while others were opposed to them clearly were unsound."); but see Marcus, History of the Modern Class Action, supra note 28, at 601 (explaining that some courts overlooked individual litigant preferences regarding potential desegregation remedies, disregarding such conflicts of interest in favor of class certification).

70. Marcus, Flawed but Noble, supra note 13, at 682-83 (emphasis added); see 7A WRIGHT, supra note 16, § 1752 at 25-26 ("there were courts that refused to permit a class action in this context"); see e.g., Carson v. Warlick, 238 F.2d 724, 729 (4th Cir. 1956) (concluding that AfricanAmerican students desegregate schools "as individuals, not as a class or group; and it is as individuals that their rights under the Constitution are asserted").

71. 311 F.2d 107 (4th Cir. 1962).

72. Brunson v. Bd. of Trustees, 30 F.R.D. 369, 369-70 (E.D.S.D. 1962).

73. See, e.g., Potts v. Flax, 313 F.2d 284 (5th Cir. 1963) (applying Texas law); Carson v. Warlick, 238 F.2d 724 (4th Cir. 1956) (applying North Carolina law); Carson v. Bd. of Educ., 227 F.2d 789 (4th Cir. 1955) (applying North Carolina law).

74. Brunson, 30 F.R.D. at 371.

75. Id. at 370 . 
school system under the Fourteenth Amendment. ${ }^{76}$ In determining whether there was a common question of law or fact that would justify certification, the district court judge espoused a particularly narrow view of Brown's desegregation mandate, and a particularly expansive view of the School Board's considerations under its pupil assignment law.

In an opinion that did not even mention Brown's name, the district court judge exhorted all of the things Brown did not decide:

It has not decided that the federal courts are to take over or regulate the public schools of the states. It has not decided that the states must mix persons of different races in the schools or must require them to attend schools or must deprive them of the right of choosing the schools they attend. $^{77}$

The judge justified segregation post-Brown by outrageously suggesting in 1962 that it was voluntary:

[I]f the schools which [the state] maintains are open to children of all races, no violation of the Constitution is involved even though the children of different races voluntarily attend different schools, as they attend different churches.... The Fourteenth Amendment is a limitation upon the exercise of power by the state or state agencies, not a limitation upon the freedom of individuals.

The judge concluded that the law was settled and that there was no common legal question to decide. The judge also concluded that there was no common question of fact by adopting the School Board's characterization of a highly individualized pupil assignment process:

In determining the school to which a pupil is entitled to go, a School Board must consider a great many factors unrelated to race, such as geography, availability of bus transportation, availability of classroom space, and scholastic attainment. ... There is no allegation in the complaint showing that the factual situation with reference to each of the plaintiffs is the same. Undoubtedly the plaintiffs reside in different places, they are of different ages, they are of different scholastic attainment. ... This [pupil assignment] statute provides that the case of each child shall be considered individually.

The School Board's divide-and-conquer strategy effectively masked the common question of whether race was the determinant for pupil

\footnotetext{
76. Id. at 372 .

77. Id. at 371 .

78. Id.

79. Id.
} 
assignments. The fact that plaintiffs were not identical sufficed to make the pupil assignment decision riddled with individual questions and the case inappropriate for certification. ${ }^{80}$ Not only did the judge swallow the School Board's manufactured individualism whole, he also concluded that the equal protection claims could only be pursued individually, thereby foreclosing collective action. ${ }^{81}$

The Fourth Circuit reversed, concluding that the plaintiffs were entitled to bring their case collectively. For starters, the Fourth Circuit was not fooled into thinking that the myriad of possible individual factors explained Clarendon County's completely segregated public school system:

[T] he defendants are operating a biracial school system in which all assignments are on the basis of race. ... The complaint does not present those disparate factual controversies which the District Court envisioned.

The Fourth Circuit concluded that threaded throughout the case was the common question of whether the School Board involuntarily assigned students on the basis of race, thereby making certification proper. ${ }^{83}$

Moreover, while conceding that it had held "that rights under the Fourteenth Amendment are individual and are to be individually asserted[,]" the Fourth Circuit observed that "comparable cases have been almost uniformly brought as spurious class actions" and involved common questions. $^{84}$ Indeed, "[u]ntil the desegregation process is largely accomplished, many subsequent cases may be expected to present common questions of fact, for many individuals are likely to be affected in substantially the same way so long as a school board continues old discriminatory practices." 85 That constitutional claims were several was no bar to collective action.

Upon the Fourth Circuit's reversal and remand, the outcome was quite different, with a different district court judge's not only certifying the

80. Id. at 372; see also Brunson v. Bd. of Trustees, 311 F.2d 107, 108 (4th Cir. 1962) (holding that the district court found "no common question of fact because the School Board was entitled to consider a great many factors other than race in assigning individuals to particular schools").

81. Brunson, 30 F.R.D. at 372 ("It is the individual who is entitled to the equal protection of the law. ... [H] alone may complain that his constitutional privilege has been invaded. He has the right to enforce this constitutional privilege or he has the right to waive it.").

82. Brunson, 311 F.2d at 109.

83. Id. In fact, the Fifth Circuit noted that "the court's consideration of these problems is facilitated by the presence of multiple plaintiffs." Id.

84. Id.

85. Id. 
class, but ordering the School Board to admit and enroll African-American students wishing to attend White schools. ${ }^{86}$ While the School District conceded that it operated racially separate White and Black elementary and high schools, and contended that this "system is maintained in accordance with the wishes and desires of the great majority of parents of both races," and "places each child in the school to which he is best suited for educational potential," $" 87$ the court issued findings of fact quite to the contrary. ${ }^{88}$ The court found that defendants continued to maintain a "compulsory biracial school system" in which no White or AfricanAmerican child had ever been assigned to a school comprised of those of the other race. ${ }^{89}$ The School District's explanations for its post-Brown segregated public school system were exposed as a sham and violation of the Constitution:

The defendants have made no substantial effort to comply with . . . the Brown decisions. . . . Neither have they proposed any plan to implement these desegregation decisions, and have indicated . . . that they have no present intentions to do so. . . . [T] his Court must conclude that the defendants . . . are acting . . . to deprive the plaintiffs and others of their class of their constitutional rights, under the due process and equal protection clauses of the Fourteenth Amendment. ... Defendants are operating the schools . . . in a discriminatory manner based exclusively upon the race of the students ... [,] precisely the practice condemned in the field of public education by ... Brown ....

Over the objections of the School District that segregated schools were in the best interests of both races and in accordance with the Fourteenth Amendment's equal protection clause, the district court judge had to reiterate that "Brown ... has clearly and unmistakenly declared that in the field of public education discrimination against an individual based upon race is injurious to the aggrieved person and denies him certain fundamental constitutional rights." ${ }^{91}$ Where the School District's pupil assignment law operated as a burden to those pursuing their constitutional claims, ${ }^{92}$ the court did not require them to exhaust state administrative remedies, but rather granted them class-wide injunctive relief. ${ }^{93}$ In sum,

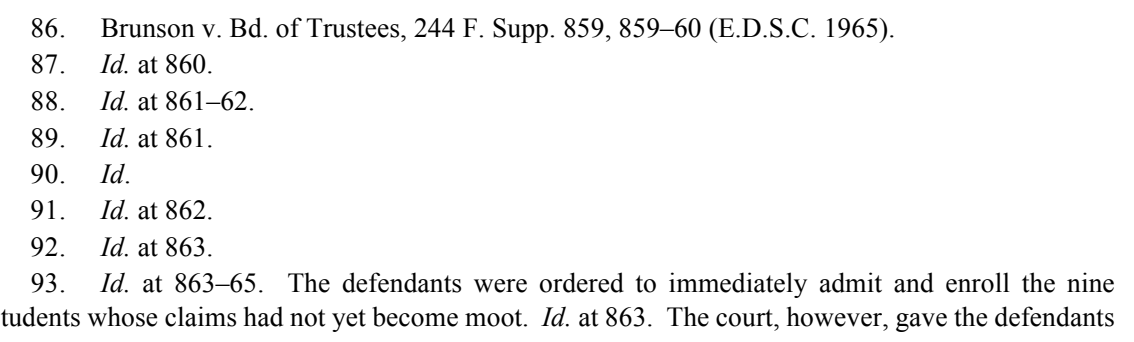


the Brunson story illustrates how malleable and subject to manipulation the class certification determination could be and was prior to the modern class action rule.

Judges also deprived litigants of meaningful relief via class certification denials in other ways. For example, an individual student's school desegregation case would be mooted by the student's graduation from his home school. ${ }^{94}$ Or, in the event that an individual student prevailed in his desegregation suit, he would be deprived of broad systemic relief that would desegregate the school for others. ${ }^{95}$

In light of such legislative and judicial tactics, the drafters sought to create a Rule 23 provision that would address such sabotage. The Advisory Committee moved to create an effective procedural tool that would more easily enable and incentivize courts to issue systemic desegregation orders post-Brown. ${ }^{96}$

Moreover, the Committee also sought to enable private citizens to supplement federal agency efforts in bringing about systemic change. The drafters understood the importance of private enforcement that emerged from historic federal civil rights statutes, such as the Civil Rights Act of $1964 .^{97}$ This Act effectively deputized citizens to act as private attorneysgeneral when enforcing federal statutory civil rights. ${ }^{98}$ As Advisory Committee Member John P. Frank revealed, Rule 23's 1966 re-write took place "in direct parallel to the Civil Rights Act of 1964 and the race relations echo of that decade was always in the committee room." 99

more time to admit others similarly situated because of practical concerns. Id. at 863-64.

94. See Marcus, Flawed but Noble, supra note 13, at 679.

95. Maureen Carroll, Class Action Myopia, 65 DUKE L.J. 843, 859 (2016); Marcus, Flawed but Noble, supra note 13, at 679-80, 710.

96. See Marcus, Flawed but Noble, supra note 13, at 709-10.

97. Civil Rights Act of 1964, Pub. L. No. 88-352, 78 Stat. 241 (1964) (codified as amended in scattered sections of 42 U.S.C.).

98. 42 U.S.C. $§ 2000$ e-5(f)(1) (2012); Albemarle Paper Co. v. Moody, 422 U.S. 405, 415 (1975) (recognizing "private attorney general" in Title VII case brought by private plaintiffs); Suzette Malveaux, A Diamond in the Rough: Trans-Substantivity of the Federal Rules of Civil Procedure and Its Detrimental Impact on Civil Rights, 92 WASH. U. L. REV. 455, 488 n.195 (2014) [hereinafter Malveaux, A Diamond in the Rough] ("As recognized by the Supreme Court and Congress, class actions are part of the Title VII enforcement scheme."); see contra Lawyers for Justice, et al, Comment to the Civil Rules Advisory Committee: To Restore a Relationship Between Classes and Their Actions: A Call for Meaningful Reform of Rule 232 (Aug. 9, 2013), http://www.uscourts.gov/sites/default/files/fr_import/13-CV-G-suggestion.pdf ("Some practitioners and commentators justify today's usage of Rule 23 as comprising a 'private attorneys general' system that forces compliance with legal standards that would otherwise escape punishment. But our legal system already has public attorneys general and many other avenues for bringing about the outcomes that are preferred by those who justify Rule 23 in that way.").

99. Frank, supra note 22, at 266. Frank further noted the importance of the "social setting, for this had a most direct bearing on this rule." $I d$. 
Interestingly, some of the rule's architects themselves were personally involved in the civil rights issue of the time-desegregation. ${ }^{100}$ Reporter Professor Benjamin Kaplan, for example, worked with the NAACP on desegregation litigation in the 1940s. ${ }^{101}$ Associate Reporter Professor Albert M. Sacks also advised the NAACP Legal Defense and Educational Fund $^{102}$ and marched with the Reverend Martin Luther King, Jr. at the March on Washington in August of 1963, just two months before a key Advisory Committee meeting was held on revisions to Rule 23. ${ }^{103}$ Committee Member Professor Charles Alan Wright worked vigorously in Texas against segregation: fighting the state legislature's enactment of pupil placement laws that would thwart Brown; leading campaigns to desegregate his church and children's private school; and later delivering a memorial address at the state university for the Reverend Martin Luther King, Jr. ${ }^{104}$ Finally, Committee Member John P. Frank, Esq. advised Thurgood Marshall of the NAACP Legal Defense and Educational Fund pre-Brown, and wrote an amicus brief on behalf of almost 200 law professors in Sweatt v. Painter, ${ }^{105}$ which held segregation at the University of Texas Law School unconstitutional. ${ }^{106}$ Primary drafters had skin in the game. ${ }^{107}$ Not surprisingly, their commitment to civil rights was consistent

100. I am grateful to Professor David Marcus for bringing this important history to my attention in his work. See Marcus, Flawed but Noble, supra note 13, at 702-03.

101. Marcus, Flawed but Noble, supra note 13, at 692, 702; see also Arthur R. Miller, In Memoriam: Benjamin Kaplan, 124 HARV. L. REV. 1354, 1357 \& n.8 (describing how "certain critical elements of Federal Rule 23 on class actions were drafted" by Kaplan and that "everyone connected with the revision of the rule saw the procedure as essential in the civil rights field").

102. Greenberg, supra note 39, at 577 (recognizing Sacks's role as an instructor at the NAACP Legal Defense and Educational Fund's training sessions over a period of years).

103. Marcus, Flawed But Noble, supra note 13, at 702-03. The Advisory Committee would meet October 31 to November 2, 1963 to discuss amendments to Rule 23. See also Alfonso A. Narvaezs, Albert M. Sacks, 70, Harvard Law Dean and Noted Teacher, N.Y. TIMES (Mar. 23, 1991), http:/www.nytimes.com/1991/03/23/obituaries/albert-m-sacks-70-harvard-law-dean-and-notedteacher.html (noting Sack's service on the United States Supreme Court Advisory Committee on Rules of Civil Procedure and Massachusetts Attorney General's advisory committee on civil rights and civil liberties).

104. Marcus, Flawed But Noble, supra note 13, at 703.

105. 339 U.S. 629 (1950).

106. Adam Liptak, J.P. Frank, 84, a Lawyer in Landmark Cases, Dies, N.Y. TiMES (Sept. 10, 2002), http://www.nytimes.com/2002/09/10/us/j-p-frank-84-a-lawyer-in-landmark-cases-dies.html.

107. Other Advisory Committee members were leaders in the desegregation efforts of the time. For example, William T. Coleman, Jr. was a pioneer in the civil rights area. Matt Schudel, William T. Coleman Jr., Barrier-Breaking Civil Rights Lawyer, Cabinet Officer, Dies at 96, WASH. Post (Mar. 31, 2017), https:/www.washingtonpost.com/national/william-t-coleman-jr-transportation-secretaryand-civil-rights-lawyer-dies-at-96/2017/03/31/94c21ce6-1624-11e7-833c-503e1f6394c9

story.html?utm_term=.6ebeaa1bd82c; see also Abraham L. Freedman Papers: Collection Overview, TEMPLE UNIV. LIBRARY, https://library.temple.edu/scrc/abraham-l-freedman-papers (last visited Nov. 21, 2017) (Advisory Committee Member Abraham Freedman was involved in desegregating Girard College, representing minorities in housing discrimination cases, and combatting employment and 
with their work on the Advisory Committee.

\section{The Story of How the Original Drafters Crafted the Modern Civil Rights Class Action Rule}

The drafters were unified around creating an effective procedural tool to address significant backlash to integration. They wrestled, however, with a variety of complex issues. The drafters debated issues of res judicata, individual liberty and due process, and the form and scope of the rule itself. ${ }^{108}$ The historical record reveals a serious examination of these seminal issues. ${ }^{109}$

\section{Res Judicata}

First, central to aggregate litigation is the extent to which a collective action will bind others and preclude them from bringing their own actions. Of particular concern over the modern class action rule's development was the res judicata effect of a class judgment and whether it would unfairly capture individual class members. The res judicata debate is reflected early on in the Committee's 1962 Deskbook. ${ }^{110}$ In this tentative proposal to modify Rule 23, there is an explication of Hansberry v. Lee, ${ }^{111}$ and the recognition of res judicata as a public policy choice. The 1962 Deskbook explains: "The Hansberry case is consistent with this view that a class action is not ousted by the mere fact that some members do not relish the litigation. Other factors were at work in Hansberry."

Hansberry v. Lee is the Supreme Court decision upon which the

education anti-Semitism discrimination); Charles Joiner Obituary (1916-2017), THE ANN ARBOR NEWS (Mar. 16, 2017), http://obits.mlive.com/obituaries/annarbor/obituary.aspx?pid= 184500638 (Advisory Committee Member Charles Joiner was a "Life Member of the NAACP"); Arthur J. Freund Papers, 1884-1975, MISSOURI HISTORY MUSEUM, http://collections.mohistory.org/ resources/102992 (Advisory Committee Member Arthur J. Freund was a "prominent St. Louis attorney and civil rights advocate").

108. See infra notes $109-181$ and accompanying text.

109. Advisory Committee member and drafter John P. Frank recognized the gravitas of the task twenty years after the rule's revision: "This was a committee which in every respect was prepared to think big. Rulemaking was a high profile and significant activity. All meetings of the committee were held in the Supreme Court building and Chief Justice Warren often dropped in for portions of the meetings." Frank, supra note 22, at 265.

110. The Deskbook is the "preliminary memorandum" of the Advisory Committee. 1962 Deskbook Topic EE: Tentative Proposal to Modify Provisions Governing Class Actions-Rule 23, in RECORDS OF THE U.S. JUDICIAL CONFERENCE, supra note 29, microformed on CIS No. CI-6309, 1 (Cong. Info. Serv.) [hereinafter 1962 Deskbook].

111. 311 U.S. 32 (1940).

112. 1962 Deskbook, supra note 110 , at 23-25, 27. 
award-winning "A Raisin in the Sun" was inspired. ${ }^{113}$ The author of the play, Lorraine Hansberry, was the youngest child of an African-American family who purchased property in an all-White neighborhood in Chicago. ${ }^{114}$ Their effort to live in the neighborhood was obstructed by Anna M. Lee and other White neighbors, who brought an action in the Circuit Court of Cook County, on behalf of themselves and other landowners, to enforce a racially restrictive covenant and enjoin the Hansberry family from moving into the neighborhood. ${ }^{115}$ The covenant, entered into by about 500 landowners, stipulated both that "for a specified period no part of the land should be 'sold, leased to or permitted to be occupied by any person of the colored race,"' and that ninety-five percent of the landowners had to have signed the agreement for it to be valid. ${ }^{116}$ Lorraine Hansberry's father, Carl Augustus Hansberry, had purchased land from an owner who had signed the agreement, leading White plaintiffs to bring a class action alleging breach of the covenant and seeking an injunction. ${ }^{117}$ However, the Hansberry family and other defendants contended that the agreement was invalid because it had not been signed by the requisite ninety-five percent. ${ }^{118}$

Plaintiffs contended that the validity of the covenant had been determined in a prior Illinois state court action, Burke v. Kleiman, ${ }^{119}$ and therefore the issue was res judicata in this case. Defendants rebutted that they could not be bound by the prior judgment because they were not parties to the prior suit nor in privity with any of the parties or successors in interest to the prior suit. ${ }^{120}$ The defendants further argued that binding them to the prior judgment in Burke v. Kleiman would deny them due process under the Fourteenth Amendment. ${ }^{121}$

No matter. The Circuit Court concluded that res judicata applied to the Hansberrys, even after finding on the merits that only fifty-four percent of the owners had signed the agreement and that the ninety-five percent

\footnotetext{
113. The play is about an African-American family who considers moving into a white neighborhood, and won the New York Drama Critics' Circle Award. ANNE CHENEY, LORRAINE HANSBERRY 26 (Twayne 1984); Jay Tidmarsh, The Story of Hansberry: The Rise of the Modern Class Action, in Civil Procedure Stories 217, 217 (Kevin M. Clermont, 1st ed., 2004). For a rich, contextualized story of Hansberry v. Lee, see generally id. at 217-79.

114. Tidmarsh, supra note 113, at 217.

115. Hansberry, 311 U.S. at $32,37-38$.

116. Id. at $37-38$.

117. Id. at $32,37-38$.

118. Id. at 38 .

119. 277 Ill. App. 519 (1934).

120. Hansberry, 311 U.S. at 38.

121. Id.
} 
figure had been the result of a "false and fraudulent stipulation."122 The Supreme Court of Illinois affirmed, concluding that the prior Burke v. Kleiman case was a class or representative action, and that the Hansberrys were members of that plaintiff class seeking to enforce the covenant and were thus bound by its decree. ${ }^{123}$ Although the stipulation about ninetyfive percent owner-support was deemed erroneous but neither fraudulent nor collusive, ${ }^{124}$ this did not change the binding nature of the prior Burke v. Kleiman class action judgment. ${ }^{125}$ The Hansberrys appealed this ruling and the United States Supreme Court granted certiorari to determine the constitutionality of binding the Hansberrys to the prior judgment.

While giving a nod to federalism, the Supreme Court made clear its role in protecting constitutional due process. ${ }^{126}$ Hansberry established that although one is not bound by a judgment in a case in which he is not a party, the significant exception to that rule is a class or representative action. ${ }^{127}$ Where a party shares the same interests as a non-party and the former adequately represents the latter's interest, a judgment in a class action comports with due process and may have res judicata effect. ${ }^{128}$ Applying this standard, the Court concluded that the Hansberrys-who sought to discredit the racially restrictive covenant - were not members of the plaintiff class in Burke v. Kleiman who sought to enforce the covenant. ${ }^{129}$ This blatant conflict of interest ran counter to due process requirements. ${ }^{130}$ Moreover, the defendants in Burke v. Kleiman had not been designated as a class of landowners resisting the covenant's performance, which could have arguably bound the Hansberrys or foreclosed their defense. ${ }^{131}$

Hansberry set a constitutional floor from which the rulemakers could establish the res judicata effect of class action decrees. The 1962 Deskbook indicates that Hansberry was a good reminder that the preclusive impact of class judgments was not a foregone conclusion, but a

\footnotetext{
122. Id.

123. Id. at 39 .

124. Id.

125. Id. at 39-40.

126. Id. at 40 .

127. Id. at $40-41$.

128. Id. at $41-43$.

129. Id. at 44-45 ("It is plain that in such circumstances all those alleged to be bound by the agreement would not constitute a single class in any litigation brought to enforce it. Those who sought to secure its benefits by enforcing it could not be said to be in the same class with or represent those whose interest was in resisting performance ....”).

130. Id. at 45 (" $[\mathrm{R}]$ epresentatives . . whose substantial interests are not necessarily or even probably the same as those whom they are deemed to represent, does not afford that protection to absent parties which due process requires.").

131. Id. at 45-46.
} 
policy choice - apropos for an equitable doctrine:

While the class action should look toward a binding adjudication as the norm, this result cannot be assured in the action itself; for the question of binding effect can only come up for effective decision in a later action. Moreover, the question of res judicata may be materially influenced by what has occurred between the time of judgment and the time the question arises for decision. For example, suppose a class action by Negro plaintiffs asserting civil rights in one or another context. The action may satisfy the requirements for a class action with, presumptively, binding effect on the class. Suppose the judgment is for the defendant. Manifestly, if the condition of law changes favorably to the asserted civil rights, the judgment will not preclude a later action by members of the class for the same relief earlier claimed. Speaking more generally, res judicata is merely the expression of one public policy, and "as the embodiment of a public policy, [it] must, at times, be weighed against competing interests, and must, on occasion, yield to other policies."

The rulemakers clashed over whether Rule 23(b)(2) would invite res judicata abuse and whether Hansberry was an effective prophylactic for such abuse. For example, in a January 21, 1963 letter from Committee Member John P. Frank to Reporter Benjamin Kaplan, Frank expressed this concern:

Without doubting for a moment the immense utility of class actions and the importance of making them available to their full proper limit, the presumption I think ought to be against them particularly where they are to be res judicata as to others because of the loss of individual liberty involved where the individual is deprived from tending to his own business. . . . With regard to your paragraph (c)(2) [the precursor to (b)(2)], I am in deep trouble. These are particularly the civil rights cases. Instinct tells me that in the civil rights field we would be better off with stare decisis, but my good friends Charlie Wright and Skelly Wright tell me I am wrong, and this may well be a case in which two "wrights" do make me wrong. My theory is that such class actions could be used to achieve res judicata results of a most destructive sort and that to permit this particular use broadens class actions beyond their other utility. Hansberry $v$. Lee gives more comfort to others than it does to me. The language you have chosen for this paragraph seems to me to have no limitation at all and that so long as enough people are involved, almost any situation could give rise to a class action. ... In short, given numbers and a common problem, the $[(b)(2)$ precursor $]$ language seems to me to include the universe and to exclude nothing.

132. 1962 Deskbook, supra note 110, at 27 (emphasis added) (citations omitted).

133. Letter from John P. Frank to Benjamin Kaplan (Jan. 21, 1963), in RECORDS OF THE U.S. JUDICIAL CONFERENCE, supra note 29, microformed on CIS No. CI-6312, 8, 9-10 (Cong. Info. Serv.) (emphasis added). 
Reporter Kaplan was assuaged that Hansberry, the rule's own adequacy of representation requirement, and the Court's flexible application of the equitable doctrine provided sufficient protection from res judicata abuse. Kaplan's February 7, 1963 letter in response to Frank explains:

As to the "binding" effect of an erroneous judgment in a civil-rights class action which for one reason or another is not corrected by appeal, note that subdivision (a) would initially call for adequate representation, and there is the backstop of Hansberry v. Lee. Moreover, ... the Court is not likely to apply ordinary ideas of former adjudication if by reason of an erroneous decision in a class action a particular school or county became a legal anomoly [sic].

Committee Member Wright also concluded that not only was Hansberry sufficient, but the concern over res judicata abuse was overblown and unfounded in the context of desegregation jurisprudence. In a February 16, 1963 letter from Committee Member Charles Wright to Reporter Kaplan, the former seemed to see res judicata abuse as a red herring that would further greenlight southern resistance to desegregation:

For myself, Hansberry seems a complete answer to such fears, but if another answer is required, here it is. For nine years astute Southern lawyers have sought by every means to stop or delay the desegregation process. That the class action device is available for desegregation cases has been amply demonstrated by a long list of cases. I have followed this kind of litigation with much care, and have yet to see a case in which a collusive class suit has even been attempted in the hope that it would have destructive res judicata effect. There is only one case I know of which is even colorably in this class, though here I think the original action was a good faith action which was merely premature. ${ }^{135}$

After much debate, the rulemakers crafted a modern rule that eliminated the non-binding "spurious" class altogether, and provided sufficient safeguards and flexibility that justified res judicata for all class judgments. Reporter Kaplan noted this advance in the October 31 st to November 2nd, 1963 Civil Rules Committee Meeting:

134. Letter from Benjamin Kaplan to John P. Frank, (Feb. 7, 1963), in RECORDS OF THE U.S. JUDICIAL CONFERENCE, supra note 29, microformed on CIS No. CI-6312, 16, 18 (Cong. Info. Serv.); see also Kaplan, supra note 39, at 389 n.128 (noting the potential risk of res judicata in a (b)(2) civil rights class action where plaintiffs have lost on the merits and the law has subsequently changed, but concluding that this risk is reduced by "precedent for limiting res judicata effects of litigation when the legal ambience has changed").

135. Letter from Charles Alan Wright to Benjamin Kaplan (Feb. 16, 1963), in RECORDS OF THE U.S. JUDiCIAL CONFERENCE, supra note 29, microformed on CIS No. CI-7004, 3,5 (Cong. Info. Serv.) (emphasis added). 
[W]e go on to the very important provision in (c)(2) which says that if an action is to be maintained as a class action of any one of the three categories, then the judgment in the action is to extend to the class, whether or not favorable to the class. In other words, we have eliminated from Rule 23 the old style spurious action, where a suit normally called a class suit isn't really that at all. It seems to me that this is a notable advance....

\section{Individual Autonomy and Due Process}

Second, the drafters were at odds over the related issue of individual litigant autonomy. John P. Frank, while a supporter of aggregation, felt strongly that it was best cabined because of its fundamental challenge to due process and individual liberty. It informed his view on res judicata, and the scope of the rule itself. ${ }^{137}$ While his colleagues, including Reporter Kaplan, shared this concern, they were satisfied that the rule contained safety measures that protected this liberty interest, ${ }^{138}$ and urged Frank to think more outside the box in amending the rule. ${ }^{139}$ At the Civil Rules Meeting held in the fall of 1963, Frank addressed the Chair:

I am, as to most of Topic ... [Rule 23], really extremely happy. I'm genuinely serious, I think this is a tremendous thing.... The class action is a very useful action, and at the same time it must be regarded as an exception, because it deprives a citizen of his right to his trial and to his day in court. So that clearly we must balance the necessity on the one hand with plain individual liberty of a very basic sort on the other. ${ }^{140}$

At the urging of his colleagues and with clarification made to the notes, by January 31, 1964, "Mr. Frank [was] reluctantly willing to see the individual's liberty somewhat limited" at least with respect to the (b)(2) class. ${ }^{141}$ This was not true of (b)(3). In his May 28, 1965 partial Dissent

136. Transcript of Sessions on Class Actions-EE, supra note 29, at 24. This was not only notable, but to some commentators, it was "by far the most important contribution of amended Rule 23" as well as "perhaps its most controversial." 1 WILliAm B. RUBENSTEIN ET AL., NEWBERG ON ClASS ACTIONS $\S 1: 15$ (5th ed. 2012).

137. See Letter from John P. Frank to Benjamin Kaplan (Mar. 22, 1963), in RECORDS OF THE U.S. JUDICIAL CONFERENCE, supra note 29, microformed on CIS No. CI-7001, 9, 9-10 (Cong. Info. Serv.) (expressing enthusiasm about the categorical statement on the binding effect of spurious class actions and expressing concern about the potential scope of the proposed rule).

138. Letter from Benjamin Kaplan to John P. Frank (Feb. 7, 1963), supra note 134, at 18, ("The question of individual freedom of action has concerned us and we believe we have respected this freedom. See ... [describing] considerations ... and ... procedural safeguards ....").

139. See id. at 18 ("A certain amount of cautious adventuresomeness is needed in revising the class-action Rule ....”).

140. Transcript of Sessions on Class Actions-EE, supra note 29, at 30-31 (emphasis added).

141. Letter from B.K. (Benjamin Kaplan) and A.M.S. (Albert M. Sacks) (Jan. 31, 1964) in RECORDS OF THE U.S. JUDICIAL CONFERENCE, supra note 29, microformed on CIS No. CI-7003, 6, 11 (Cong. Info. Serv.). 
to the Committee's Rule 23 recommendations, Frank opposed the (b)(3) provision, largely because it offended individual autonomy:

I would . . . delete section (b)(3) and the related portion of section (c)(2) [binding class members] for these reasons: ...

To me as a matter of plain individual liberty, every American should be able to make his own decisions about his own lawsuits, including whether to bring them at all. Any class suit conflicts with this principle - a person is swept up will-nilly. In some very limited categories, this is necessary .... [But t] he notion that this may be a convenient way to dispose of disputes leaves me stone-cold. It is not difficult to think of convenient ways to do many things at the cost of individual liberty, but convenience should never be glorified at the expense of leaving with the individual the maximum possible right to decide whom and when he sues.

Fundamentally, . . . the Rule 23 amendments, to the extent of my objection, involve determining the rights of persons who are not really effectively present to speak for themselves. Because I am against this justitia in absentia, I have voted against . . . [some of the Rule 23] proposals. $^{14}$

Ultimately, however, the rulemakers coalesced around permitting aggregation for (b)(2) civil rights cases, allowing some loss of individual autonomy where class cohesiveness was insured by opposing party's acting on grounds generally applicable to the class and seeking primarily class-wide injunctive or declaratory relief.

\section{Scope and Structure of the Rule}

Third, the drafters clashed over the appropriate availability of aggregation and breadth of the rule. For example, some rulemakers expressed concern over the scope of Rule 23(b)(1)'s pre-cursor, fearing that it would include mass accidents. ${ }^{143}$ In a January 21, 1963 letter to Reporter Kaplan, Committee Member Frank flagged this concern early in the revision process:

We now reach the heart of the matter, and it is here that I have my

142. Advisory Committee on Civil Rules Dissenting View of Committee Member John P. Frank (May 28, 1965), in RECORDS OF THE U.S. JUDICIAL CONFERENCE, supra note 29, microformed on CIS No. CI-7107, 2, 2-3 (Cong. Info. Serv.) (emphasis added).

143. See Letter from Benjamin Kaplan to John P. Frank (Feb. 7, 1963), supra note 134, at 17 ("[Y]ou fear that the mass accident cases may creep in through [the Rule 23(b)(1) pre-cursor]. I, too, am anxious to keep them out."). 
greatest difficulty. . . . I wish we could have tighter language on the matters covered in your paragraph (c)(1) [Rule 23(b)(1)'s pre-cursor]. . . . But the Rule language is so broad that an immense amount more could get under this tent. Let me illustrate. I am, I believe, unpersuadably opposed to the use of the class action in the mass tort situation. You seem, though less categorically opposed, unsympathetic to it yourself. ${ }^{144}$

This concern, however, was not shared for the civil rights cases. Frank lost consensus there. In response to Frank, in a February 7, 1963 response letter, Reporter Kaplan discouraged such a cramped conception for civil rights cases:

I agree with you that subdivision (c)(2) [Rule 23(b)(2)'s pre-cursor] needs very careful attention, and we should continue to search for better language so that unintended categories do not come in. I do not, however, share your concern about taking in civil rights cases. On analysis they seem to belong in the (c) category.

If a school desegregation case, for example, is maintained by an individual on his own behalf, rather than as a class action, very likely the relief will be confined to admission of the individual to the school and will not encompass broad corrective measures - desegregation of the school. This would be unfortunate. But if the relief is to encompass broad corrective measures, then it is fitting that the action be conducted as a class action.

I may add that if the action is not maintained as a class action, the contempt remedy would presumably not be available to anyone but the individual plaintiff, and others in similar position could be put to separate proceedings with ensuing delay.

This desire to protect desegregation cases from legislative and judicial backlash led to a related debate over the form of the rule itself. In particular, the drafters differed over the propriety of creating a separate (b)(2) provision rather than including civil rights cases under Rule 23(b)(1). Rule 23(b)(1), as amended, would allow a class action to be maintained if:

$[\mathrm{P}]$ rosecuting separate actions by or against individual class members would create a risk of:

144. See Letter from John P. Frank to Professor Benjamin Kaplan (Jan. 21, 1963), in ReCORDS OF THE U.S. JUDICIAL CONFERENCE, supra note 29, microformed on CIS No. CI-6312, 8, 9-10 (Cong. Info. Serv.).

145. See Letter from Benjamin Kaplan to John P. Frank (Feb. 7, 1963), supra note 134, at 17-18 (paragraph breaks added). 
(A) inconsistent or varying adjudications with respect to individual class members that would establish incompatible standards of conduct for the party opposing the class; ${ }^{146}$ or

(B) adjudications with respect to individual class members that, as a practical matter, would be dispositive of the interests of the other members not parties to the individual adjudications or would substantially impair or impede their ability to protect their interests[.] ${ }^{147}$

Alternatively, Rule 23(b)(2) would allow a class action to be maintained so long as "the party opposing the class has acted or refused to act on grounds that apply generally to the class, so that final injunctive relief or corresponding declaratory relief is appropriate respecting the class as a whole[.]"148

John P. Frank argued on a number of occasions that Rule 23(b)(1) - a mandatory, binding class action that subsumed the vast majority of "true" class actions - offered a logical home for civil rights cases, thereby making (b)(2) redundant. ${ }^{149}$ On March 22, 1963, he wrote his fellow colleagues:

As I see it, [the lines in Rule 23(b)(2)] are not necessary to reach the civil rights cases. These are covered perfectly well (to me) by subdivision (1). ... I can't imagine more inconsistent results than a possible holding that a school should be segregated as to one applicant and not as to another. ${ }^{15}$

His colleagues were unpersuaded. Committee Member Charles Alan Wright shared his skepticism to Reporter Benjamin Kaplan in a March 30, 1963 letter:

John Frank's proposal to drop subdivision[] (2) . . of Rule 23(b) is not,

146. FED. R. CIV. P. 23(b)(1)(A). The Advisory Committee Note provides the following example: "individual litigations of the rights and duties of riparian owners ... could create a possibility of incompatible adjudications." FED. R. CIV. P. 23 advisory committee's notes to 1966 amendment.

147. FED. R. CIV. P. 23(b)(1)(B). The Advisory Committee Note provides the following example: "when claims are made by numerous persons against a fund insufficient to satisfy all claims." FED. R. CIV. P. 23 advisory committee's notes to 1966 amendment.

148. FED. R. CIV. P. 23(b)(2).

149. Letter from John Frank to Benjamin Kaplan (Mar. 22, 1963), supra note 137, at 9, 11.

150. Id.; see also Memorandum from B.K. (Benjamin Kaplan) and A.M.S. (Albert M. Sacks) on Additional Points on Preliminary Draft of Proposed Amendments of March 15, 1963, in RECORDS OF THE U.S. JUDICIAL CONFERENCE, supra note 29, microformed on CIS No. CI-7001 (Cong. Info. Serv.), 19, 21 ("Mr. Frank has suggested that (b)(2) may be unnecessary in the light of (b)(1)(A) and (B)(p. EE-1)"); Completion of Work of Comm. Meeting of Oct. 31-Nov. 2, 1963, in RECORDS OF THE U.S. JUDICIAL CONFERENCE, supra note 29, microformed on CIS No. CI-7104, 4, 7-11 (Cong. Info. Serv.) (contending that (b)(2) and (b)(3) are unnecessary and that there is nothing worth doing under these provisions that cannot be done under $(\mathrm{b})(1)(\mathrm{A})$ and $(\mathrm{b})(1)(\mathrm{B}))$. 
at first blush, persuasive to me. I do not think that (b)(1) by itself would reach the segregation cases. It would not "establish incompatible standards of conduct for the party opposing the class" to tell a school board that it must accept Smith in a white school but need not accept Jones. This is exactly what the Fort Worth School Board wanted to be told in Potts v. Flax. Nor do I see how a judgment that Smith must be accepted would "as a practical matter be dispositive of the interests of the other members not parties to the adjudications or substantially impair or impede their ability to protect their interests." I would be delighted to drop all of (b), but oppose dropping (b)(2).

At the October 31st to November 2nd, 1963 Civil Rules Meeting, John P. Frank, while recognizing the importance of desegregation class actions, reiterated his disapproval of the (b)(2) option:

I think we've got it in parts (b)(1)(A) and (B), that is to say if we reviewed the great bulk of the cases - and I'm now speaking of $95 \%$ of the cases which have been true class actions in the past, i.e. have been regarded as binding - they fall into those categories [quoting A and B]. . .. Those then become the two base situations. Now as to those, the class action is essential. ... As to those I think under the existing law it is binding, but if it isn't it should be....

Therefore, when we take class (2), which are said to be the segregation cases, I am satisfied from extensive correspondence with Professor Wright and extensive conference with Judge Skelly Wright, ${ }^{152}$ and a review of the cases, that the integration cases need to be class actions. . .. But I believe they can be wholly subsumed by sections (A) and (B) of part (1). In other words, these can be treated, I think, as varying adjudications which would establish incompatible standards of conduct etc.-if one Negro is let in and another is held back. I think that ${ }_{153} a$ beefy note on that score we can cover that under (1)(A) adequately. ${ }^{153}$

Reporter Benjamin Kaplan and Committee Member Charles Alan

151. Letter from Charles Alan Wright to Benjamin Kaplan (Mar. 30, 1963), in RECORDS OF THE U.S. Judicial CONFERENCE, supra note 29, microformed on CIS No. CI-7001, 13, 15 (Cong. Info. Serv.).

152. Judge Skelly Wright was appointed by President Kennedy to serve on the United States Court of Appeals for the District of Columbia. Wright grew up in New Orleans where he attended all-white public high schools. He went on to become a "pioneer in the desegregation of public schools and public transportation in his native New Orleans." Marjorie Hunter, Judge J. Skelly Wright, Segregation Foe Dies at 77, N.Y. TIMES (Aug. 8, 1988), http://www.nytimes.com/ 1988/08/08/obituaries/judge-j-skelly-wright-segregation-foe-dies-at-77.html. Judge Wright's advice to the Advisory Committee was informed by his own expertise and experience involving desegregation. As Marjorie Hunter notes "In the months after his order to integrate the public schools in New Orleans in 1960, Judge Wright was shunned by old friends. A cross was burned on the lawn of his home. Telephone threats against his life became so numerous that police guards were assigned to protect him." Id.

153. Transcript of Sessions on Class Actions-EE, supra note 29, at 32 (emphasis and paragraph break added). 
Wright balked at the notion that civil rights cases could be shoehorned into a (b)(1) class, noting the ease with which those opposed to integration could defeat class certification. Kaplan responded to Frank at the Civil Rules Meeting as follows:

Well, I would consider the elimination of those lines [re: (b)(2)] to be so retrograde a move that I don't think we could go to the public with a rule so truncated. To take your first point first, John [Frank], you are saying that in your view the ordinary desegregation case can be read under (1)(A) or (B). Let me make first the observation that if by any chance the desegregation case could be found by a judge not to be a class action after the adoption of the rule, we would of course be in a very, very bad way. If there is any doubt on the matter, we certainly ought to carry language which includes the desegregation suit. So, if there be any question about it, (2) ought to remain in.

Second, I don't think the desegregation case is covered by either (1)(A) or (B), because I think that the cases leave open the distinct possibility that a Negro child may apply on his own behalf for admission to school and would be entitled to a decree in his favor alone. I don't think that a series of such suits would create "inconsistent or varying adjudications establishing incompatible standards of conduct" by the Board. There are plenty of Boards who would be very happy to be engaged in what you call "incompatible standards of conduct." Nor do I think that an adjudication with respect to an individual (this is (B)) would be decisive of the issues of the class. Now the cases suggest that this argument stands on the proposition that we have not got a law which says, as you seem to suggest it says, that an individual Negro student cannot maintain an action on his own. So on all scores it seems to me that (2) must remain in to make it absolutely clear that desegregation cases - and (2) is not confined to deseg. but that can be taken as characteristic - to make sure that those cases are covered. ${ }^{154}$

Wright made the same objections, flagging the propensity of local school boards and judges to successfully defeat and deny class certification based on a "divide and conquer" approach:

Mr. Chairman, John [Frank] has again in his motion given what seem to me two very different problems. On (2) I feel so strongly that he is wrong that once you agree, as he does, that segregation cases must be prosecuted as class actions (as certainly they must) you have to have (2) to take care of them. It is simply torturing language to say that they involve "incompatible standards of conduct" and come under (1)(A).

The proof of that I think is in the action of several Boards: the Fort Worth School Board in the case of [redacted], which said Yes, we'll take [redacted], but we don't want the order to require us to take other

154. Id. at 33-34 (emphasis and paragraph break added). 
Negroes. They found nothing incompatible. The Clemson Board of Trustees, after they had already admitted Gantt, petitioned for certiorari unsuccessfully to have the class action aspects stricken from the decree. Or you can look to the decree which the district judge actually entered in Baily v. Paterson in Miss. after they had once won the case in the Supreme Court, and the decree was entered providing that the bus company must transport the three named plaintiffs without discrimination, but it could [illegible] to refuse all other Negroes. These people opposing the class don't find it incompatible.

I don't think it is incompatible. So I think we must take care of these cases. I don't see that (2) is open to the dangers to which John [Frank] adverts, which I think may be very real dangers in (3).

In rejecting desegregation cases for Rule 23(b)(1) certification, the Committee members considered a number of cases, including Brunson and Potts, discussed supra, which illustrated the type of strong resistance to desegregation post-Brown and the course corrections needed. ${ }^{156}$

Tellingly, much of the Committee's criticism over potential amendments to Rule 23 was targeted to provision (b)(3). Rule 23(b)(3) allows a class action to be maintained where "the court finds that the questions of law or fact common to class members predominate over any questions affecting only individual members, and that a class action is superior to other available methods for fairly and efficiently adjudicating the controversy." 157 This catch-all provision would bind classes far less cohesive than those contemplated under provisions (b)(1) and (b)(2), held together for convenience and efficiency brought about by the predominance of common questions. Many "spurious" classes and those involving money damages could be accommodated by the (b)(3) provision.

There was more consensus among the rulemakers that provision (b)(3) broke new ground and risked opening a Pandora's box that could not be closed. ${ }^{158}$ To the extent that the rulemakers perceived this risk as bleeding

\footnotetext{
155. Id. at 35 (emphasis and paragraph breaks added).

156. Memorandum from B.K. (Benjamin Kaplan) and A.M.S. (Albert M. Sacks), supra note 150, at 21 ("Our proposed Rule 23(b)(2) (pp. EE-1-2), intended to reach a group of cases including the segregation cases, is supported with particular cogency by the opinions in Brunson v. Board of Trustees of School District No. 1 of Clarendon County, S. C., 311 F. 2d 107 (4th Cir. 1962), and Potts v. Flax, 313 F.2d 284 (5th Cir. 1963) (both cited at p. EE-12), on which Professor Wright distributed a memorandum dated February 16, 1963. Please note that certiorari was denied in Brunson on May 27, 1963, 83 Sup. Ct. 1538. See also Gantt v. Clemson Ag. College of S.C., 6 F.R. Serv. 2d 23a.33, case 8 (4th Cir. 1963).").

157. FED. R. CIV. P. 23(b)(3).

158. See Carroll, supra note 95, at 861-63 (describing the controversial nature of the (b)(3) provision and reticence among the drafters to include it in the modern class action rule).
} 
over into provision (b)(2), they were critical of both provisions. John P. Frank, in particular, seemed to conflate the two provisions, criticizing both in the same breath, despite their very different nature. ${ }^{159}$

For example, Committee Member Frank sought to reign in what he saw as unbridled judicial discretion to certify cases under (b)(2) and (b)(3), ${ }^{160}$ believing that this could lead to an abuse of power:

My opposition to divisions (2) and (3) is that they put no limit but the sky to class actions, leaving the entire matter to discretion in the particular case. It must be remembered that despite the excellent notice provisions of the Rule, this is a discretion which must be exercised in the dark so far as the court is concerned. The possibility of put-up jobs in strike suits is tremendous. ${ }^{161}$ I find nothing at all substantial in the materials . . . indicating any particular necessity for this wide open area.

I would far rather take the excellent revision as you have it without these open door provisions and give them ten years for development. ${ }^{162}$

To the extent that Frank's disapproval applied to the (b)(3) class, his colleagues shared his reservations. For example, in a March 30, 1963 letter from Committee Member Charles Alan Wright to Reporter Benjamin Kaplan, Wright remarked:

John Frank's proposal to drop subdivisions (2) and (3) of Rule 23(b) is not, at first blush, persuasive to me. ... I would be delighted to drop all of (b), but oppose dropping (b)(2). On (b)(3) I am dubitante. ${ }^{16}$

At the October 31st to November 2nd, 1963 Civil Rules Meeting, Frank-while recognizing the importance of desegregation class actions - reiterated his disapproval of (b)(2) along with (b)(3):

As to the rest of it, namely part (2), and part (3) I myself do not believe it is at all necessary or proper to have class actions at all. Remember always that these are binding, because we have eliminated the nonbinding class action. I do not think that there is anything really worth doing under (2) or (3) that we cannot consume under (1)(A) or (B)

\footnotetext{
159. See generally id. (describing this conflation in the modern context).

160. See supra note 144 and accompanying text.

161. This refers to a pre-arranged lawsuit brought by plaintiffs to encourage settlement by the defendant where it would cost the latter less to settle than to litigate the case. This concern would seem to fit proposed Rule 23(b)(3) more than (b)(2).

162. Letter from John Frank to Benjamin Kaplan (Mar. 22, 1963), in RECORDS OF THE U.S. JUdicial CONFERENCE, supra note 29, microformed on CIS No. CI-7001, 9, 11 (Cong. Info. Serv.) (emphasis added).

163. Letter from Charles Alan Wright to Benjamin Kaplan (Mar. 30, 1963), supra note 151, at 15 (emphasis added).
} 
adequately, because I am so genuinely concerned about the interference with individual liberty and the possibility of fraud. I do not wish to see the class action made any more useful and usable than it has to be....

Mr. Chairman, to conclude, I believe that the social values involved by allowing sections (2) and (3) to become class actions at all, despite the isolated instances which are suggested, are far less valuable contributions than the detriment that comes from opening the doors to those practices and depriving those people of their rights. And I therefore would move to delete [the language of Rule 23(b)(2) and (b)(3)] of the proposal. ${ }^{164}$

At that Civil Rules Meeting, Committee members distinguished (b)(2) from (b)(3) in their response to Frank. For example, Kaplan explained:

When I spoke of a truncated rule being retrograde, I had in mind very much classification (3). . . . I grant you that the class action has to be carefully handled, but what closer safeguards can we provide than the ones we have. So I would very much hope that we would not excise either of these categories [(b)(2) or $\left.{ }_{165}(b)(3)\right]$. I think it's of the utmost importance that they be preserved. ${ }^{165}$

Another example is Wright's reaction:

So I think we must take care of these cases. I don't see that (2) is open to the dangers to which John [Frank] adverts, which I think may be very real dangers in (3). ${ }^{166}$

While there are genuine differences between (b)(2) and (b)(3) classes, Reporter Kaplan argued that the former could not exist without the latter. In an exchange with Committee Members Frank and Wright at the fall 1963 Civil Rules Meeting, Reporter Kaplan posited that both provisions are necessary for the greater good:

Mr. Frank: Mr. Chairman, may I explain. ... [W]hat's in [(b)](3) now, that's as [Associate Reporter] Al[bert Sacks] has suggested, largely the present spurious class action, and they aren't res judicata now. So what we're doing here is working a plain revolution, because we're taking actions which would not have been res judicata and we're making them res judicata.

Kaplan: Now John [Frank], the very desegregation suits that are now being conducted are theoretically spurious class actions, but there isn't

\footnotetext{
164. Transcript of Sessions on Class Actions-EE, supra note 29, at 32-33 (emphasis and paragraph break added).

165. Id. at 34 (emphasis added).

166. Id. at 35 (emphasis added)
} 
a judge in the world that's treating them that way, nor should they be treated that way.

Mr. Frank: But we must separate those. You and Charlie [Wright] feel that is a section (2) problem. We're confining ourselves at the moment to section (3).

Kaplan: But I'm saying that the same thing is carrying over. We are in the midst of a very important development which will enable courts to deal with diffuse litigation, and when you put a negative to (b)(3) you are chopping off that development with a knife, and let's be perfectly clear that that's what's being done. I say that it is incredible to me that we can go forward with a revision of the class suit rule and chop that development off and make it suitable. I don't see it. It's not possible. ${ }^{167}$

For Frank, that (b)(2) and (b)(3) were so intertwined was a bridge too far. In a painful example, he illustrates the purported futility of $(b)(3)$ in a legal system that already offers alternative options for resolving duplicative litigation outside of aggregation:

In my state, Judge Wyzanski ${ }^{168}$ - I regret to say this - we kill an awful lot of Mexicans, and we do it by hauling them around in busses that are wholly inadequate. We had seventeen killed in our state in one accident; California had 27 not so long ago. These become compensatory cases, but we've had great success (particularly under Judge Boldt, a member of our central Committee, who came down and handled one of them) using devices which weren't class actions, didn't sacrifice anybody's rights, but on the other hand were damned efficient, and we moved them through, and with a little pushing he got four sample cases and they moved those and accepted those results and we were done with them. . . . I confess that I am now ready to vote yes on all the rule except (3), tighten (2), and go home and be happy.

In recognition of the importance of creating an aggregate vehicle for desegregation cases in particular, Frank ultimately yielded to the inclusion of (b)(2). Although Frank is an outlier in his view over which vehicle is best suited for civil rights enforcement, he shared the Committee's commitment in providing one. ${ }^{170}$ His concern was over the scope of (b)(2)'s coverage, not its civil rights objective:

\footnotetext{
167. Id. at 41 (emphasis added).

168. For background on Judge Wyzanski, see Eric Pace, Charles E. Wyzasnki, 80, is Dead; Judge on U.S. Court for 45 Years, N.Y. TIMES (Sept. 5, 1986), http://www.nytimes.com/1986/09/05/ obituaries/charles-e-wyzanski-80-is-dead-judge-on-us-court-for-45-years.html (noting he "won wide note with rulings on issues large and small in the 1960's and the Vietnam War era").

169. Transcript of Sessions on Class Actions-EE, supra note 29, at 51 (emphasis added).

170. See also id. at 61 (emphasis added) (Advisory Committee Member Judge Roszel C. Thomsen: "We certainly want (2) to cover the segregation cases.").
} 
Lines 25 to 28 [covering Rule 23(b)(2)] are included here because of the belief that they are needed to be sure that we cover the segregation case. I do not personally believe that to be so, in the sense that I believe that they can be perfectly adequately covered above; however, opinions that I am bound to respect come to the contrary conclusion, and so I yield the point, because certainly we want the segregation cases covered somewhere here.

However, in the course of covering the segregation cases, we have in lines 25-28, I think, covered the universe as well. The party opposing the class has acted or refused to act on grounds generally applicable to the class, thereby making-in other words, for that reason-making appropriate specific or declaratory final relief with respect to the class as a whole. Now, that covers the segregation cases alright, but it also covers matters which almost everybody in this room doesn't have the faintest wish to cover, because this also in terms covers mass accidents.

In any case of a mass accident where the asserted negligent party refuses to act, i.e., refuses to pay on grounds generally applicable to the class; to wit, denial of negligence, thereby we have a more than plausible, we have a probably interpretation that this covers that. It covers, in short, any conceivable refusal on the part of anybody to refuse to do what a large number of persons wish done, and that, it seems to me, is no possible basis for depriving individual American citizens of their rights to independent trials by itself.

After much hard work and careful thought, the civil rights provision of the modern class action rule-Rule 23(b)(2) - -was approved. ${ }^{172}$ Even in his dissenting view, Frank applauded the goals achieved by the modern class rule:

$[\mathrm{P}] \operatorname{arts}(\mathrm{b})(1)$ and (2) absorb the former true and hybrid class actions; (b)(2) picks up the contemporary use of class actions in the race relations cases; and section (c)(2) makes judgments in these cases binding on the class. The revision also greatly improves the devices to protect the class from abuse. For these improvements, I applaud.

Ultimately, Committee Member Frank could not embrace the most controversial aspect of the modern aggregation rule ${ }^{174}$ - the Rule 23(b)(3)

171. Id. at 60-61 (emphasis and paragraph breaks added).

172. See Order Approving Amendments to Federal Rules of Civil Procedure, 383 U.S. 1031 (1966).

173. Advisory Committee on Civil Rules Dissenting View of Committee Member John P. Frank (May 28, 1965), supra note 142, at 2 (emphasis added).

174. John P. Frank, Response to 1996 Circulation of Proposed Rule 23 on Class Actions, supra note 22, at 267 ("As a member of the committee, I dissented from the (b)(3) portion of the rule ...."); id. ("[T]he most sharply disputed question was whether to have Rule (b)(3) at all."). 
catch-all. ${ }^{175}$ His partial Dissent focuses on this provision:

But having done so much good, the Rule proceeds to go an unnecessary and undesirable extra mile. By section (b)(3) the Rule absorbs the old, spurious class action, and section (c)(2) makes this also binding on the class. At this point a majority of my brothers and I part company. ... I would therefore delete section (b)(3) and the related portion of section (c)(2) [making the class judgment binding] for ... reasons [including . . .t]he corruption potential of the binding spurious class action intimidates me. These cases are terribly easy to rig - a bright child could do it. I would not hold out the bait. ${ }^{\text {.7 }}$

Rule 23(b)(3) eventually passed muster because of a rule provision that allowed class members to opt-out of a (b)(3) class. ${ }^{177}$ While this opportunity for self-exclusion did not satisfy Frank, ${ }^{178}$ it gave sufficient comfort to other previously skeptical Committee members. ${ }^{179}$ Reporter Kaplan concluded that (b)(3) was an important step forward:

This [Rule 23(b)(3)] in fact is a growing point in the law. This is the situation that ought to be covered, left to some extent to the discretion of the court. As we all know, cases involving large numbers of persons are

175. See Letter from B.K. (Benjamin Kaplan) and A.M.S. (Albert M. Sacks) (Jan. 31, 1964), supra note 141, at 6-7, 11("With respect to the (b)(1) and (b)(2) categories, Mr. Frank is reluctantly willing to see the individual's liberty somewhat limited, but he balks at (b)(3), which he views as a kind of luxury category that is not really necessary or important.").

176. Advisory Committee on Civil Rules Dissenting View of Committee Member John P. Frank (May 28, 1965), supra note 142, at 2-3 (paragraph breaks omitted).

177. Current Rule 23(c)(2)(B) states:

For (b)(3) Classes. For any class certified under Rule 23(b)(3), the court must direct to class members the best notice that is practicable under the circumstances, including individual notice to all members who can be identified through reasonable effort. The notice must clearly and concisely state in plain, easily understood language: ...

(v) that the court will exclude from the class any member who requests exclusion; ....

FED. R. CIV. P. 23(c)(2)(B).

178. Advisory Committee on Civil Rules Dissenting View of Committee Member John P. Frank (May 28, 1965), supra note 142, at 4 ("That if the individual [in a (b)(3) class] knows of the action, he can 'opt out' by disclaimer gives me zero comfort.").

179. Frank describes how the opt-out resolved the (b)(3) problem:

It was at that moment that committee member Judge Charles Wyzanski had his flash of genius. He responded to Professor Moore, "Would you be satisfied, Professor Moore, if the class could never include anybody who specifically protests within a given period?" Professor Moore responded, "That would be helpful" and the principal opponent of (b)(3) added, "If that were done, my problem would evaporate." ... [T] he rule was adopted .... John P. Frank, Response to 1996 Circulation of Proposed Rule 23 on Class Actions, supra note 22, at $269-70$. 
more and more almost the staple of federal litigation. It is at this point that we make an advance.

In sum, the drafters of the modern class action rule were unwavering in their commitment to create a procedural mechanism for the enforcement of civil rights, as illustrated by their deliberations. ${ }^{181}$ Creation of the modern Rule 23's civil rights provision went on to become a procedural force with which to be reckoned.

\section{MAJOR TRENDS IN RULE 23(B)(2) JURISPRUDENCE OVER THE LAST FIFTY YEARS}

\section{A. The Heyday of Civil Rights Class Actions}

Modern Rule 23's civil rights provision, coupled with the historic Civil Rights Act of 1964, empowered ordinary people to achieve extraordinary outcomes through the court system. Fueled by public interest litigation and the growth of statutory rights and constitutional claims, federal courts certified civil rights cases impacting broad classes and providing far-reaching relief. ${ }^{182}$ Civil rights class actions were brought to challenge all manner of segregation and discrimination in areas such as education, housing, public accommodations, and employment. ${ }^{183}$

Employment discrimination class actions under Title VII of the Civil Rights Act of 1964 typified the law enforcement role of Rule 23(b)(2) in the 1960s and 1970s. ${ }^{184}$ Pursuant to this rule, the federal courts regularly certified cases enjoining broad discriminatory policies and individually

180. Transcript of Sessions on Class Actions-EE, supra note 29, at 25.

181. In coming to a resolution over including (b)(2), the drafters also wrestled with the propriety of money damages being available under the provision. Although the rule is silent on the issue, they concluded in the accompanying note that so long as money damages did not predominate, it was permissible. FED. R. CIV. P. 23(b)(2) advisory committee's notes to 1966 amendment ("The subdivision does not extend to cases in which the appropriate final relief relates exclusively or predominantly to money damages.").

182. See, e.g., Marcus, History of the Modern Class Action, supra note 28, at 639-40; Greenberg, supra note 39, at 585 ("In . . . prisoners' rights, school desegregation, and employment discrimination-class actions have played a vital role. They have made it possible to afford relief to large numbers of persons who, realistically, could not have been parties to litigation."); see also id. at 581 (describing broad remedies in school desegregation cases that typified the early 1970s).

183. Greenberg, supra note 39, at 576 (discussing the "critical role" class action has played in civil rights litigation); 7AA WRIGHT, supra note 29, § $1776 \mathrm{nn}$. 6-9 ("Rule 23(b)(2) has been invoked in a wide range of civil rights contexts: suits arising out of alleged race and sex discrimination in employment; in school and housing desegregation or discrimination suits.") (citing cases).

184. See Greenberg, supra note 39, at 583 ("Class actions have played a major role in employment discrimination litigation."); id. (surmising that "establishing the propriety of class relief had a high priority" for courts). 
compensating employees for back pay-because of its equitable nature. ${ }^{185}$ Indeed, the first Title VII case heard by the Supreme Court in 1966 affirmed the availability of class treatment to counter employment discrimination under the statute. ${ }^{186}$

Moreover, during this time period, courts allowed "across-the-board" class actions-enabling named plaintiffs challenging one discriminatory practice to represent broadly other groups and to challenge other practices under the umbrella of a single class action. ${ }^{187}$ Some courts did not bother to determine if the Rule 23(b) criteria had been satisfied, concluding that aggregation was appropriate for cases enjoining segregation and discrimination. $^{188}$

Class actions also spearheaded a broader conception of civil litigation that resulted in expansive injunctive relief and systemic reform to major institutions such as prisons, foster care and public welfare. ${ }^{189}$ The traditional model of "bipolar litigation between two private parties, in which the remedy is retrospective and self-contained" had to give way to a model that joined multiple parties with public and private interests, in which the remedy was forward-looking and extensive. ${ }^{190}$

Prison reform is illustrative. ${ }^{191}$ Efforts to reform "large, inefficient, abusive, unconstitutional prison systems" that had been stymied for decades were green-lighted through aggregate litigation. ${ }^{192}$ In 1968, for example, the Supreme Court held in Lee v. Washington that racial

185. Suzette M. Malveaux, Class Actions at the Crossroads: An Answer to Wal-Mart v. Dukes, 5 HARV. L. \& POL'Y REV. 375, 391-96 (2011) [hereinafter Malveaux, Crossroads] (describing how back pay, as an equitable remedy, was regularly available in a (b)(2) class action).

186. See Greenberg, supra note 39, at 583 (referring to Gen. Tel. Co. of Sw. v. Falcon, 457 U.S. $147(1982))$.

187. Marcus, History of the Modern Class Action, supra note 28, at 641-43.

188. See 7AA WRIGHT, supra note $29, \S 1776$ \& n.14 (citing cases).

189. See id., § 1776 \& n.10 (noting that "Rule 23(b)(2) has been invoked in a wide range of civil rights contexts: ... in actions challenging public-welfare statutes or regulations as discriminatory" and citing cases); Edward F. Sherman, Introduction to the Symposium: Complex Litigation: Plagued by Concerns Over Federalism, Jurisdiction and Fairness, 37 AKRON L. REV. 589, 591 (2004) (citing cases).

190. Greenberg, supra note 39, at 576-77. Jack Greenberg, citing the work of Professor Abram Chayes, describes the shift as follows: "Courts of equity have come to enter more broadly based decrees; the remedies have shifted from one-shot, one-way transfers to compensate for past wrongs, to decrees adjusting future behavior." Id. at 576 (citing Abram Chayes, The Role of the Judge in Public Law Litigation, 89 HARV. L. REV. 1281, 1291 (1976)).

191. Greenberg, supra note 39, at 577 ("Class actions have played a major role in securing the rights of prisoners. Since the federal class action rule was revised in 1966, prisoner rights litigation has utilized the mechanism of class action to bring broad relief to inmates and detainees throughout the country.").

192. Id. at 576; see also id. at 577-78 (describing various rights advocated on behalf of prisoners in the class action context). 
segregation of prisoners was a violation of the Fourteenth Amendment. ${ }^{193}$ The injunctive and declaratory relief was not cabined to only the specific prisoners challenging segregation, but rather covered all prisoners in the Alabama penal system. ${ }^{194}$ Aggregation did what stare decisis could do, but with far less expenditure of judicial resources and lawsuits. ${ }^{195}$

Aggregation also did what stare decisis failed to do. ${ }^{196}$ The Second Circuit's holding in Marcera v. Chinlund ${ }^{197}$ illustrates this. ${ }^{198}$ Although the court had in at least three prior class actions determined pre-trial detainees' rights to contact visits, the relief was cabined to those particular prisoners in those particular prisons. ${ }^{199}$ Marcera expanded the scope of relief to a class of prisoners state-wide, putting an end to piecemeal, seriatim enforcement and relief. ${ }^{200}$ Not surprisingly, the class action device became a popular tool for major prison reform where constitutional violations were clearly established. ${ }^{201}$

In sum, the combination of Congress's prolific creation of statutory rights coupled with the federal judiciary's robust certification of systemic, injunctive civil rights cases resulted in a heyday of impactful civil rights litigation.

\section{B. Retraction of Civil Rights Aggregation and the Damages Conundrum}

This heyday would not last forever. The perfect storm of statutory construction of rights and procedural access to aggregation in the courts started to calm in the late $1970 \mathrm{~s} .{ }^{202}$ The pendulum began to swing towards a more cabined approach as the Supreme Court reined in robust certification of civil rights cases. $^{203}$

\footnotetext{
193. Lee v. Washington, 390 U.S. 333, 334 (1968).

194. Greenberg, supra note 39 , at 578.

195. Id.

196. See id. ("Stare decisis did not seem to be operating.").

197. Marcera v. Chinlund, 595 F.2d 1231, 1242 (2d Cir. 1979), vacated, Lombard v. Marcera, 442 U.S. 915 (1979).

198. Greenberg, supra note 39, at 578.

199. Marcera, 595 F.2d at 1234-35.

200. Greenberg, supra note 39, at 578.

201. Id. ("Prisoners' rights litigation came to use the class action mechanism frequently and to the fullest extent possible.); see also Marcera, 595 F.2d at 1240 (rejecting judicial administrative inconvenience and federalism concerns as justifications for "excus[ing] a failure to remedy clear constitutional violations").

202. See Greenberg, supra note 39 , at 579-84.

203. Having said that, in 1984, "civil rights class actions represented $37.3 \%$ of all class action suits - the largest of any single category." Greenberg, supra note 39, at 576 (citing Angelo N. Ancheta, Defendant Class Actions and Federal Civil Rights Litigation, 33 UCLA L. REV. 283, 330 n.2 (1985)).
} 
More specifically, while recognizing that "suits alleging racial or ethnic discrimination are often by their very nature class suits, involving classwide wrongs," the Court's 1977 decision in East Texas Motor Freight System, Inc. v. Rodriguez cautioned that "careful attention to the requirements of [Rule 23] remains nonetheless indispensable." 204 In that vein, in 1982, the Court, in General Telephone Co. of the Southwest v. Falcon, rebuked the "across-the-board" approach in an employment discrimination case. ${ }^{205}$ That is, a victim of racial discrimination could no longer attack all unequal employment practices "across-the-board" that were subject to an employer's policy. Instead, the Court held that class representatives had to be members of the class they sought to represent and had to "possess the same interest and suffer the same injury" of class members. ${ }^{206}$ In Falcon, the Court held that where an employee alleged that he had been denied a promotion on account of being MexicanAmerican, he could not adequately represent a class of Mexican-American applicants who were not hired on account of similar discrimination. ${ }^{207}$ Falcon marked a turning point; the Court made clear that a naked allegation of race discrimination in employment was no longer the sine qua non for class certification. ${ }^{208}$ Instead, certification of a Title VII employment discrimination case was contingent upon a "rigorous analysis" of the Rule 23 criteria. ${ }^{209}$

Following Falcon, the number of employment discrimination class actions filed in federal court dropped precipitously. For example, in 1976, 1174 employment discrimination class actions were filed in federal court. ${ }^{210}$ By 1991, that number had dropped to thirty-two. ${ }^{211}$ Retreat of

204. E. Tex. Motor Freight Sys., Inc. v. Rodriguez, 431 U.S. 395, 405 (1977). In Rodriguez, the Court reversed class certification on the grounds that the named plaintiffs were inadequate representatives because they were not members of the class. Id. at 403-04. Mexican-American city truck drivers who were not qualified to be line drivers did not suffer injury and thus could not represent a class of those African-American and Mexican-Americans who were so qualified. Id. at 396, 398400, 403-05. The Court reiterated that the "mere fact that a complaint alleges racial or ethnic discrimination does not in itself ensure that the party who has brought the lawsuit will be an adequate representative of those who may have been the real victims of that discrimination." Id. at 405-06.

205. Gen. Tel. Co. of the Sw. v. Falcon, 457 U.S. 147, 160 (1982).

206. Id. at 156 (quoting Rodriguez, 431 U.S. at 403).

207. Id. at $149,158-59$.

208. Id. at 157 ; see also id. at 159 ("If one allegation of specific discriminatory treatment were sufficient to support an across-the-board attack, every Title VII case would be a potential companywide class action. We find nothing in the statute to indicate that Congress intended to authorize such a wholesale expansion of class-action litigation.").

209. Id. at 161.

210. Melissa Hart, Will Employment Discrimination Class Actions Survive?, 37 AKRON L. REV. 813, 820 (2004).

211. Id. 
the public interest movement and growth of corporate political power led to fewer Title VII class actions being used as a conduit for social change.

By the late 1990s and early 2000s, the number of employment discrimination class actions increased slightly, leveling off at seventythree to eighty-five annually. ${ }^{212}$ This uptick was due, in part, to the enactment of the Civil Rights Act of $1991,{ }^{213}$ which amended the Civil Rights Act of 1964. ${ }^{214}$

The Civil Rights Act of 1991 responded to a number of 1989 Supreme Court cases viewed as hostile to civil rights enforcement. ${ }^{215}$ One of those was Martin v. Wilks, ${ }^{216}$ which dealt with the scope of relief a court could provide in a class action. In this case, African-American firefighters brought a class action alleging employment discrimination in pay and promotions. $^{217}$ The parties settled the case and the court issued a consent decree with an affirmative action plan that resulted in some White firefighters not being appointed. ${ }^{218}$ The latter contended that the decree discriminated against them and improperly bound them as non-parties in the prior case. ${ }^{219}$ The Supreme Court ruled in their favor. ${ }^{220}$ Congressin a rare show of overwhelming support ${ }^{221}$ _overruled Wilks in the Civil Rights Act of $1991 .^{222}$ In a nutshell, where the White firefighters had notice and an opportunity to be heard, and adequate representation in the prior class action, they could be bound to the class decree without being parties. $^{223}$

In addition to reversing a number of unfavorable civil rights rulings, the 1991 Act amended the 1964 Act to promote greater deterrence of

\footnotetext{
212. Id.

213. 42 U.S.C. $§ 1981$ (2012); see Greenberg, supra note 39, at 584 (noting in 1997 that "employment . . . class actions of considerable scope continue to be filed"); $i d$. at 585 (noting that in 1997, employment discrimination cases "classes [were] becoming larger, back pay relief [was] increasing dramatically, and the Civil Rights Act of 1991 [was] restoring the gains of previous litigation.").

214. Hart, supra note 210, at 813.

215. Id. at 825; Greenberg, supra note 39, at 584 ("The Civil Rights Act of 1991 overturned Martin v. Wilks and various other decisions which curtailed the scope of Title VII.").

216. 490 U.S. 755 (1989).

217. Id. at 759 .

218. Id.

219. Id. at $760-61$.

220. Id. at 761-64.

221. See Greenberg, supra note 39, at 584 ("[T] civil rights statute in American history, with eighty-nine percent of Congress voting in favor.").

222. Pub. L. No. 102-166, § 108, 105 Stat. 1071, 1076 (1991) (codified at 42 U.S.C. § 2000e$2(\mathrm{n})(1)(\mathrm{B}))$

223. Greenberg, supra note 39 , at 584.
} 
harassment and intentional discrimination. ${ }^{224}$ This course correction included providing compensatory and punitive damages and a right to a jury trial in employment cases alleging intentional discrimination. ${ }^{25}$

Although designed to promote greater civil rights enforcement, the 1991 Act had the unintended consequence of creating division among the federal circuit courts of appeals over the availability of monetary damages for Rule 23(b)(2) classes. ${ }^{226}$ Although all of the circuits that considered the issue concluded that monetary relief was permissible so long as it did not predominate over the injunctive and declaratory relief sought, ${ }^{227}$ the appellate courts used different tests when determining predominance. ${ }^{228}$ This split made some circuits less amenable to certifying Title VII cases seeking monetary damages under Rule 23(b)(2).

The more rigorous certification approach was promoted by the Fifth Circuit in Allison v. Citgo, which conditioned certification on monetary damages being incidental to the injunctive or declaratory relief sought. ${ }^{229}$ Damages had to "flow directly from liability to the class as a whole." 230 Applying this stringent standard, the court concluded that the compensatory and punitive damages sought required individualized proof, and were therefore not incidental, and Rule 23(b)(2) certification was denied. $^{231}$ The Seventh and Eleventh Circuits likewise adopted this approach. ${ }^{232}$

In contrast, the Ninth Circuit opted for a more flexible ad hoc balancing approach to the Fifth Circuit's bright-line test. ${ }^{233}$ The Second Circuit's Robinson v. Metro-North decision emphasized lower court discretion and determined whether the weight or value of the injunctive and declaratory relief predominated over the monetary damages from the

\footnotetext{
224. Hart, supra note 210 , at 826 .

225. Id. at $813-14,826$.

226. Suzette M. Malveaux, How Goliath Won: The Future Implications of Dukes v. Wal-Mart, 106 Nw. U. L. Rev. ColloQuY 34, 49-50 (2011); 7A Wright, supra note 16, § 1776, at 93-94; see also 7A WRIGHT, supra note $16, \S 1784.1$.

227. See Greenberg, supra note 39 , at 828 .

228. Id. at 830 .

229. Allison v. Citgo Petroleum Corp., 151 F.3d 402, 415 (5th Cir. 1998).

230. Id. (citing FED. R. CIV. P. 23(b)(2)).

231. Id. at 418. This conclusion also meant that Rule 23(b)(3) certification was not appropriate because individualized questions predominated over common ones, in contravention of this rule's requirements. Id. at 420; see also FED. R. CIV. P. 23(b)(3).

232. See Murray v. Auslander, 244 F.3d 807, 812 (11th Cir. 2001); Jefferson v. Ingersoll Int'l Inc., 195 F.3d 894, 898 (7th Cir. 1999).

233. See Dukes v. Wal-Mart Stores, Inc., 603 F.3d 571, 616 (9th Cir. 2010), rev'd, 564 U.S. 338 (2011).
} 
plaintiffs' eye. ${ }^{234}$ Other courts took a compromised position, choosing to allow hybrid certification. ${ }^{235}$ For example, a court might certify class-wide liability under Rule 23(b)(2) and individual monetary damages under Rule $23(b)(3){ }^{236}$

The Supreme Court ultimately resolved the issue, adopting the incidental test, even where plaintiffs sought back pay under Rule 23(b)(2). ${ }^{237}$ In Wal-Mart v. Dukes, the Court concluded that since the back pay had to be determined on an individualized basis, rather than formulaically, the monetary relief was not incidental and Rule 23(b)(2) certification was not allowed. $^{238}$

This ruling has the effect of funneling much of employment discrimination class actions seeking monetary, in addition to injunctive, relief from $23(\mathrm{~b})(2)$ to $23(\mathrm{~b})(3)$ consideration $^{239}$ - a higher bar to clear. ${ }^{240}$ Consequently, the civil rights class action rule born of the 1960 s-i.e., (b)(2) - is less likely to be home to litigants seeking systemic change if they are also seeking monetary relief.

In sum, following the civil rights movement, the next couple of decades were marked by the Supreme Court's reining in aggregate litigation as a readily available procedural tool for addressing racial and other inequality on a wide scale. Litigants could no longer sweep with as broad a brush over discriminatory practices and actors as before. This retraction would continue into the next century, but with more attention than ever to the class action device.

\section{Contemporary Challenges to Combatting Systemic Discrimination in}

\footnotetext{
234. Robinson v. Metro-N. Commuter R.R., 267 F.3d 147, 164 (2d Cir. 2001).

235. Hart, supra note 210, at 829-30.

236. Id. at 824 .

237. See Wal-Mart Stores, Inc. v. Dukes, 564 U.S. 338, 366 (2011). The courts have historically recognized the importance of back pay as a prophylactic for employment discrimination and an incentive for voluntary compliance with Title VII. Greenberg, supra note 39, at 584 (citing Albemarle Paper Co. v. Moody, 422 U.S. 405, 421 (1975)).

238. Wal-Mart, 564 U.S. at 362-63.

239. See John C. Coffee, Jr. \& Alexandra D. Lahav, Battered but Unbowed: A 2016 Update on Class Actions, in The 20TH AnNual National Institute on Class Actions D1, D-21 (A.B.A. 2016), http://www.americanbar.org/content/dam/aba/events/cle/2016/10/ce1610cac/ce1610caccor. authcheckdam.pdf.

240. Suzette M. Malveaux, The Power and Promise of Procedure: Examining the Class Action Landscape After Wal-Mart v. Dukes, 62 DePaul L. Rev. 659, 667, 671 (2013); Malveaux, A Diamond in the Rough, supra note 98, at 501-04 (describing Rule 23(b)(3) obstacles); see also, e.g., FED. R. CIV. P. 23(c)(2)(B). The heightened notice requirement, for example, makes a Rule 23(b)(3) class potentially more expensive. Moreover, the requirement that common questions predominate over individual ones and that a class action be superior to other procedural approaches also makes Rule 23(b)(3) potentially more difficult to satisfy.
} 
the Aggregate

The twentieth century has ushered in a renewed interest in civil procedure and aggregate litigation with the swearing in of Chief Justice John G. Roberts, Jr. ${ }^{241}$ Over the past decade, the Supreme Court has grappled with an exceptional number of class actions. ${ }^{242}$

There are several possible reasons for this. The uptick in certiorari grants in the field may be explained by the fact that aggregation issues have had ample time to ripen into circuit splits and to reveal their importance to the long game. ${ }^{243}$ Significantly, the inordinate volume may be explained by a greater number of class actions in the federal pipeline due to the more recent discretionary availability of interlocutory review of certification orders under Rule 23(f), ${ }^{244}$ and enhanced federal jurisdiction over major class actions under the Class Action Fairness Act (CAFA). ${ }^{245}$ Some have attributed the growth to the composition of the Court itself, noting the Justices' backgrounds in litigating federal cases and teaching civil procedure, their politics, ${ }^{246}$ and their capacity to effect procedural change relative to the rulemaking process and Congress. ${ }^{247}$

This recent re-awakening of class action jurisprudence over the past ten years ${ }^{248}$ has had mixed results for litigants challenging systemic discrimination. This section examines the Supreme Court's use of worthiness as a screen for class certification, ${ }^{249}$ deference towards the enforceability of class action waivers, and policing of statutory, constitutional and evidentiary doorways to the civil litigation system. These broad areas provide a window into understanding how the Court's contemporary jurisprudence impacts litigants' ability to effectively challenge systemic discrimination using Rule 23(b)(2) today. ${ }^{250}$

241. Howard M. Wasserman, The Roberts Court and the Civil Procedure Revival, 31 Rev. Litig. 313,314 (2012).

242. Id. at $314-15$.

243. See id. at 338-45.

244. FED. R. CIV. P. 23(f). Rule 23 was amended in 1998 to allow such discretionary interlocutory review. FED. R. CIV. P. 23(f) advisory committee's note to 1998 amendments.

245. Class Action Fairness Act of 2005, Pub. L. No. 109-2, 119 Stat. 4 (2005) (codified in scattered sections of 28 U.S.C.).

246. Wasserman, supra note 241, at 330-32.

247. Id. at 333-34.

248. Id. at $314-15$.

249. This article does not examine the Court's treatment of the merits in cases involving other substantive areas of law, such as securities and antitrust.

250. For example, issue certification and ascertainability are issues percolating in the courts below. See Chad R. Fuller et al., A Serious Circuit Split on Class Ascertainability, Law360 (June 30, 2016, 4:42 PM), https://www.law360.com/articles/813021/a-serious-circuit-split-on-class- 
1. Worthiness as a Screen: The Consideration of Merits at Class Certification

The Court's insistence that judges conduct a demanding analysis of the propriety of aggregation has clearly calcified. Nowhere is that more apparent than in the Court's treatment of the merits at the class certification stage. Although judges are not permitted to condition certification on whether the putative class will ultimately prevail, they are free to consider the merits to the extent that they overlap with the certification criteria. ${ }^{251}$ This overlapping determination of the elements of a cause of action and the elements of Rule 23 has firmly taken root, putting to rest any doubt initially created by Eisen v. Carlisle \& Jacquelin. ${ }^{252}$ In 1974, Eisen made clear that it was not appropriate to condition class certification on a case's probability of success:

We find nothing in either the language or history of Rule 23 that gives a court any authority to conduct a preliminary inquiry into the merits of a suit in order to determine whether it may be maintained as a class action. Indeed, such a procedure contravenes the Rule by allowing a representative plaintiff to secure the benefits of a class action without first satisfying the requirements for it. ${ }^{253}$

Notwithstanding Eisen's disallowing the aggregation determination to rise or fall on a case's merits, a court may inquire into merits that overlap with certification criteria. ${ }^{254}$ The seminal case that confirmed this in the civil rights context is Wal-Mart v. Dukes. ${ }^{255}$

In Wal-Mart, plaintiffs' allegations of a pattern or practice of Title VII employment discrimination were interlaced with Rule 23's requirement that the case involve common questions of law or fact. ${ }^{256}$ Like its predecessors, Wal-Mart reiterated the necessity for rigor and the movant's burden of proof at the class certification stage. ${ }^{257}$

But unlike prior case law, Wal-Mart conditioned its finding of "commonality" on plaintiffs' having to put forth "“[s]ignificant proof" that

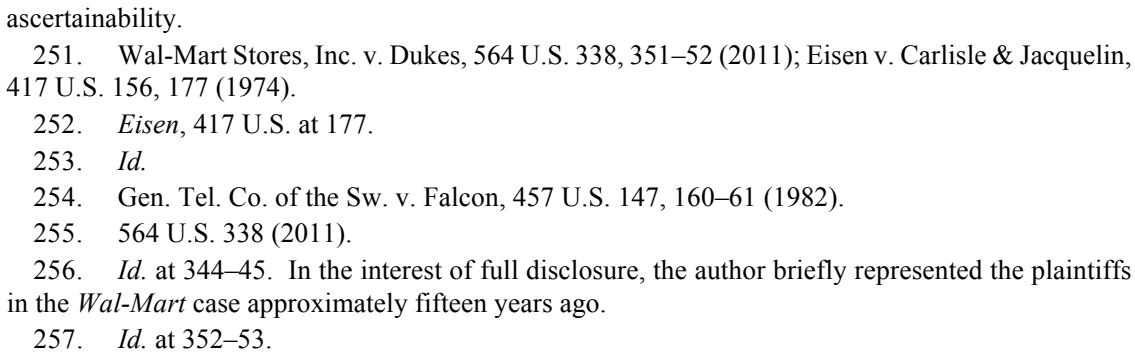


[the employer] 'operated under a general policy of discrimination.",258 Arguably the easiest of Rule 23's gatekeeper provisions, commonality became the blockade for 1.5 million women's ${ }^{259}$ attempt to collectively challenge their employer for alleged nationwide gender discrimination. ${ }^{260}$

To prevail in a pattern or practice case on the merits, plaintiffs must ultimately prove, inter alia, that a discriminatory policy (formal or informal) exists. ${ }^{261}$ Plaintiffs seeking class certification must now put forth "significant proof" that that predicate has been met, just to bond as a class. $^{262}$ Thus, the criteria for commonality not only overlaps with the merits, but aligns more closely with plaintiffs' likelihood of prevailing on the merits in a systemic discrimination claim. In other words, worthiness becomes a screening device for collective access to the court in systemic discrimination cases. This proves problematic where a court may rely on its own prejudgments and worldview when determining whether there is sufficient proof of a discriminatory policy's existence. ${ }^{263}$

This foreshadowing function is precisely what Eisen rejected. ${ }^{264}$ Class certification is not the juncture at which a judge should speculate about a case's viability. ${ }^{265}$ Neither is it the vehicle through which a judge should impede a later determination on the merits. Class certification and merits are like overlapping tectonic plates; a slight shift can have a major effect on the civil litigation landscape.

Applying this higher commonality burden of proof, Wal-Mart decertified the case on the grounds that there was "not enough glue" to hold the case together as a class action. ${ }^{266}$ Not unlike the desegregation cases of the 1960's - where school boards manufactured individualized

\footnotetext{
258. Id. at 353 (quoting Gen. Tel. Co. of the Sw., 457 U.S. at 159 n.15).

259. Id. at 342 .

260. Id. at 357.

261. See id. at $352-55$.

262. Id. at 353 (emphasis added).

263. See A. Benjamin Spencer, Class Actions, Heightened Commonality, and Declining Access to Justice, 93 B.U.L. REV. 441, 445 (2013) (describing how Wal-Mart's heightened commonality standard stemmed in part from "[c]laimant animus, combined with hostility toward and a misunderstanding of claims of discrimination"); see also Malveaux, A Diamond in the Rough, supra note 98, at 492-99 (describing the Wal-Mart majority's incredulity that a majority of male mangers could exercise their discretion in a way that disadvantages female employees).

264. See Eisen v. Carlisle \& Jacquelin, 417 U.S. 156, 177 (1974).

265. Two years after Wal-Mart, the Court's rhetoric swung back to a more cabined approach. Amgen Inc. v. Conn. Ret. Plans \& Tr. Funds, 586 U.S. 455, 465-66 (2013) (citing Wal-Mart Stores, Inc. v. Dukes, 564 U.S. 338, 350-51 (2011)) ("Rule 23 grants courts no license to engage in freeranging merits inquiries at the certification stage. Merits questions may be considered to the extentbut only to the extent- that they are relevant to determining whether the Rule 23 prerequisites for class certification are satisfied.").

266. Wal-Mart, 564 U.S. at 352
} 
pupil assignment factors like geography, bus transportation routes, age, and student aptitude to deflect a court away from the real determinant "race"-Wal-Mart did the same regarding gender in the employment context. $^{267}$ Highlighting the fact that pay and promotion decisions were made by different supervisors, in different stores, at different times, for different jobs, etc. - the employer was able to deflect attention away from the real and systemic determinant "gender."

How has Wal-Mart's heightened commonality impacted other civil rights cases? What ripple effect has resulted and what are the implications of even this small wave? For every action, there is an equal and opposite reaction. This has certainly been the case regarding the pragmatic response to Wal-Mart's heightened commonality standard. A half-dozen years post-Wal-Mart, litigants and judges have shaped the parameters of the case's reach. It has certainly become more difficult for litigants to challenge highly discretionary discriminatory conduct on a class-wide basis post-Wal-Mart. ${ }^{268}$ However, recognizing the Court's reticence to certify a class of over 1.5 million class members nationwide, other litigants have sought certification of cases of far less enormity and breadth. ${ }^{269}$ Putative classes are now more narrowly defined, geographically limited, and divided into subclasses. ${ }^{270}$ Plaintiffs have turned to state courts as a potentially more receptive venue for granting class certification. ${ }^{271}$

An excellent example of recalibration post-Wal-Mart is the robust development of jurisprudence regarding issue certification. ${ }^{272}$ When

267. This isn't to suggest that Wal-Mart and the school board cases are on the same scale or aren't distinct in significant ways.

268. Tabor v. Hilti, Inc., 703 F.3d 1206, 1229 (10th Cir. 2013) (“After Wal-Mart, federal courts reviewing class certification questions have generally denied certification when allegedly discriminatory policies are highly discretionary and the plaintiffs do not point to 'a common mode of exercising discretion that pervades the entire company." (quoting In re Wells Fargo Residential Mortg. Lending Discrimination Litig., No. 08-MD-01930 MMC, 2011 WL 3903117, at*4-5 (N.D. Cal. Sept. 6, 2011))).

269. See Seyfarth Shaw llp, Annual Workplace Class action litigation Report: 2014 EDITION 2-6 (2014), http://www.workplaceclassaction.com/wp-content/uploads/sites/214/ 2014/01/CAR-2014.pdf.

270. See Michael Selmi \& Sylvia Tsakos, Employment Discrimination Class Actions After WalMart v. Dukes, 48 AKRON L. REV. 803, 829-30 (2015); see, e.g., Anne Bucher, New Wal-Mart Gender Discrimination Class Action Lawsuit Filed, TOP Class ACTIONS (Nov. 10, 2017), https://topclassactions.com/lawsuit-settlements/lawsuit-news/825782-new-walmart-genderdiscrimination-class-action-lawsuit-filed/,.

271. Malveaux, A Diamond in the Rough, supra note 98, at 499, 499 n.268 (citing Kumar v. Gate Gourmet, Inc., 325 P.3d 193 (Wash. 2014)).

272. See Challenging Limited Issue Class Actions, Foley \& LARDNER LLP (Apr. 27, 2017), https://www.foley.com/challenging-limited-issue-class-actions-04-27-2017/ (discussing "growing trend" of relying on issue classes and changes in "tactics and strategies employed by all parties" postWal-Mart). 
possible, litigants are seeking to certify a particular issue ${ }^{273}$ rather than an entire claim, ${ }^{274}$ and some courts are granting this tapered request. As civil rights claimants move from Rule 23(b)(2) to (b)(3), discussed supra, they must meet the latter's strictures of proving that common issues predominate over individual ones for class certification. ${ }^{275}$ Litigants, however, are also able per Rule 23(c)(4) to seek certification of a single issue where appropriate. Thus, specific issues related to liability have been cordoned off and subjected to class treatment, over objections that this undermines Rule 23(b)(3)'s requirement that common questions predominate over individual ones.

Courts and commentators are divided ${ }^{276}$ over whether a judge must consider a plaintiff's entire claim when determining whether common issues predominate over individual ones under (b)(3), and then apply (c)(4) to certify a particular issue; or whether a judge may extract a particular issue per (c)(4), and then consider predominance per (b)(3). The Second, Third, Fourth, Seventh and Ninth Circuits have supported the latter approach, albeit using different methods. ${ }^{277}$ The Fifth Circuit has taken

273. Rule 23(c)(4) states: "When appropriate, an action may be maintained as a class action with respect to particular issues." FED. R. CIV. P. 23(c)(4).

274. See Seyfarth Shaw LlP, 13th Annual Workplace Class action Litigation REPORT: 2017 EDITION 26 (2017) [hereinafter SEYFARTH SHAW LLP, 2017 REPORT], http://www.workplaceclassaction.com/wp-content/uploads/sites/214/2017/01/CAR-2017-Chapter-1FINAL.pdf ("In terms of certification theories, the plaintiffs' bar is apt to pursue hybrid or parallel class certification theories where injunctive relief is sought under Rule 23(b)(2) and monetary relief is sought under Rule 23(b)(3), as well as a range of partial 'issues certification' theories under Rule 23(c)(4).").

275. See FED. R. CIV. P. 23(b)(3).

276. Compare John C. Coffee, The New Class Action Landscape: A Trail Map to Class Certification and Practice after Wal-Mart and Concepcion, in THE 15TH ANNUAL NATIONAL Institute ON Class ACTIONS A1, A-102 (A.B.A. 2011), with Mark A. Perry, Issue Certification Under Rule 23(c)(4): A Reappraisal, 62 DePAUL L. ReV. 733, 733-34 (2013).

277. See In re Nassau County Strip Search Cases, 461 F.3d 219, 226-27 (2d Cir. 2006) (approving of issue certification); McLaughlin v. Am. Tobacco Co., 522 F.3d 215, 234 (2d Cir. 2008) (issue certification approved when it would "reduce the range of issues in dispute and promote judicial economy"); Gates v. Rohm \& Haas Co., 655 F.3d 255, 272 (3d Cir. 2011) (adopting approach from PRinCiPLES OF THE LAW OF AGgRegate Litigation § 2.02 (AM. LAW. Inst. 2010)); McReynolds v. Merrill Lynch, Pierce, Fenner \& Smith, Inc., 672 F.3d 482, 491 (7th Cir. 2012) (approving issue certification in cases where there are "genuinely common issues, issues identical across all the claimants ... the accuracy of the resolution of which is unlikely to be enhanced by repeated proceedings" (quoting Mejdrech v. Met-Coil Systems Corp., 319 F.3d 910, 911 (7th Cir. 2003)); Valentino v. Carter-Wallace, Inc., 97 F.3d 1227, 1234 (9th Cir. 1996) ("Even if the common questions do not predominate over the individual questions so that class certification of the entire action is warranted, Rule 23 authorizes the district court in appropriate cases to isolate the common issues under Rule 23(c)(4)(A) and proceed with class treatment of these particular issues."). The Rule 23 Subcommittee to the Advisory Committee on Civil Rules recently considered amendments to Rule 23 that would make issue certification easier. 
the former approach, ${ }^{278}$ but retreated somewhat, ${ }^{279}$ leading some to conclude that there is more consensus on the matter. ${ }^{280}$

Given the judicial economy and efficiency that aggregate litigation offers, it's no wonder that many federal court judges are trending toward permitting some limited aggregation in the (b)(3) context. To the extent that systemic discrimination cases are housed here, issue certification should remain.

Moreover, issue certification should be available for Rule 23(b)(2) classes. ${ }^{281}$ Injunctive civil rights cases often have discrete issues-such as the existence and impact of a particular policy - that warrant certification on efficacy grounds. ${ }^{282}$

In addition to constricting the edges of the litigation form, litigants and judges have conceptually cabined Wal-Mart Stores, Inc. v. Dukes by distinguishing it from similar cases. In Wal-Mart, plaintiffs contended that the employer gave its local managers unfettered discretion when making salary and promotion decisions, to the detriment of its female employees. ${ }^{283}$ Plaintiffs alleged that this excessive subjectivity was the vehicle for nationwide gender discrimination by a workforce managed largely by men in a culture that promoted unchecked gender stereotyping. ${ }^{284}$ In this environment, male supervisors at stores all over the country allegedly exercised their discretion in a discriminatory

278. See Castano v. Am. Tobacco Co., 84 F.3d 734, 745 n.21 (5th Cir. 1996) (“A district court cannot manufacture predominance through the nimble use of subdivision (c)(4).").

279. See In re Deepwater Horizon, 739 F.3d 790, 806 \& n.66, 816-17 \& n.122 (5th Cir. 2014) (agreeing with Sixth, Seventh and Ninth Circuits in concluding that district court did not abuse its discretion in certifying Rule 23(b)(3) class where liability and damages determinations were bifurcated under Rule 23(c)(4) and district court reserved damages issues for individual determinations).

280. For example, the Rule 23 Subcommittee to the Advisory Committee on Civil Rules decided to forego amending Rule 23 to address issue certification because of this evolving consensus. Notes of September 11, 2015 Subcommittee Meeting, in ADVISORY COMMITTEE ON CIVIL RULES AGENDA BOOK FOR NOVEMBER 2015 151, 151 (2015), http://www.uscourts.gov/sites/default/files/2015-11civil-agenda_book.pdf. In contrast to the majority of circuits and the rulemakers, Congress is advocating for the stricter issue certification approach. The measure passed the House of Representatives on March 9, 2017, but has since stymied. See H.R. 985, 115th Cong. § 1720 (2017); Class Action Issues Update November 2017, AM. ANTITRUST INST. (Nov. 6, 2017), http://www.antitrustinstitute.org/content/class-action-issues-update-november-2017.

281. See Letter from Jocelyn D. Larkin, Exec. Dir., Impact Fund, to Comm. on Rules of Practice and Procedure 4 (Sept. 4, 2015) [hereinafter Larkin Letter], http://www.uscourts.gov/sites/ default/files/2017-01-04-testimony_and_comment_handout.pdf.

282. See id.; Letter from Leslie A. Brueckner, Senior Att'y Public Justice, to Rule 23 Subcomm. of the Judicial Conference Advisory Comm. on Civil Rules 6 (Sept. 8, 2015), http://www.uscourts.gov/sites/default/files/2017-01-04-testimony_and_comment_handout.pdf (criticizing approach that would amend Rule 23 to deal with issue certification in (b)(3) context, while improperly precluding issue certification in (b)(2) cases).

283. Wal-Mart Stores, Inc. v. Dukes, 564 U.S. 338, 344-45 (2011).

284. See id. 
manner, although perhaps subconsciously, while the company's leadership intentionally looked away. ${ }^{285}$ Plaintiffs offered workforce statistics, individual affidavits and social science data as significant proof that the employer operated under a general policy of discrimination-i.e., imbuing local supervisors with excessive discretion when making personnel decisions that adversely affected women's employment opportunities. ${ }^{286}$ Plaintiffs alleged, effectively, that it was the wild, wild, west.

But for the Court, the company's lack of a policy being the discriminatory policy was a bridge too far. ${ }^{287}$ This was especially true where the company also had, at least on paper, a formal, written antidiscrimination policy. ${ }^{288}$ Where such a written policy existed, the Court was incredulous that a majority of supervisors would exercise their discretion in a way that harms the employment opportunities of women. ${ }^{289}$ Given the recent onslaught of sexual harassment employment discrimination claims industry-wide in Hollywood and elsewhere, this incredulity seems even less justified.

The Court inexplicably paid undue homage to a relatively standard corporate practice - i.e., a company providing boilerplate language that formally forbids discrimination - in the Court's assessment of whether there was significant proof of a discriminatory policy. Certainly, subjective decision-making that permits implicit bias to go unchecked may co-exist with a formal discrimination prohibition.

In any event, not surprisingly, in other cases where putative class members allege the same type of policy of excessive subjectivity as a vehicle for discrimination as in Wal-Mart, they have suffered a similar fate. ${ }^{290}$ Their cases have not been certified-inside and outside the Title VII context.

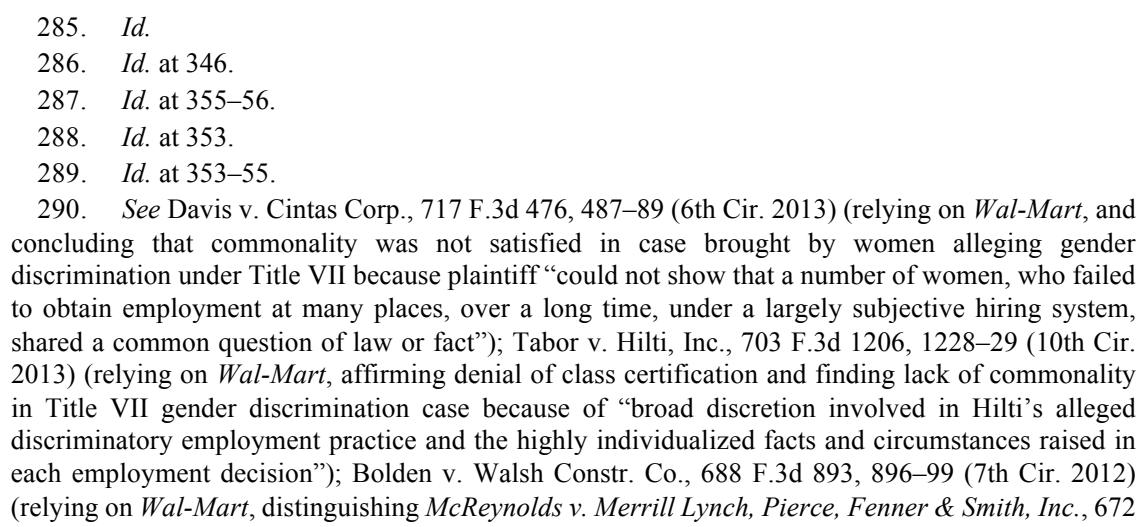
to obtain employment at many places, over a long time, under a largely subjective hiring system, shared a common question of law or fact"); Tabor v. Hilti, Inc., 703 F.3d 1206, 1228-29 (10th Cir. 2013) (relying on Wal-Mart, affirming denial of class certification and finding lack of commonality in Title VII gender discrimination case because of "broad discretion involved in Hilti's alleged discriminatory employment practice and the highly individualized facts and circumstances raised in each employment decision”); Bolden v. Walsh Constr. Co., 688 F.3d 893, 896-99 (7th Cir. 2012) (relying on Wal-Mart, distinguishing McReynolds v. Merrill Lynch, Pierce, Fenner \& Smith, Inc., 672 
Other courts, however, have distinguished Wal-Mart, despite the fact that the litigants identified discretionary practices as potentially harmful to group rights. For example, in McReynolds v. Merrill Lynch, Pierce, Fenner \& Smith, Inc., the Seventh Circuit (Judge Posner) overturned the denial of class certification where local branch and regional managers exercised their discretion pursuant to explicit companywide national teaming and account distribution policies. ${ }^{291}$ Alternatively, in Scott v. Family Dollar Stores, the Fourth Circuit vacated and remanded the denial of class certification where the upper-level managers of the company themselves exercised the challenged discretion. ${ }^{292}$ In these cases, commonality was satisfied despite plaintiffs' allegations that discretionary practices were discriminatory and far-reaching.

The distinction between these cases and Wal-Mart can be explained by how close the nexus is between the allegedly discriminatory decisionmakers and corporate policy. In McReynolds, although those who made the adverse discretionary decisions were local, low-level managers, their actions were tightly connected to centralized, nationwide policies created at the corporate level. ${ }^{293}$ In Scott, those who made the adverse discretionary decisions were high-level managers, who exercised such centralized power and control that their actions were equivalent to corporate policy. ${ }^{294}$

In Wal-Mart, the employer deliberately chose to decentralize power ${ }^{295}$ and to widely disburse it among its supervisory personnel who were allegedly left unchecked and prone to potential bias (implicit or explicit) in making personnel decisions. ${ }^{296}$ Conceptually, there seems little

F.3d 482 (7th Cir. 2012), reversing class certification, and finding lack of commonality in case brought by African-American construction workers alleging race discrimination under Title VII because "local discretion cannot support a company-wide class no matter how cleverly lawyers may try to repackage local variability as uniformity"); Bennett v. Nucor Corp., 656 F.3d 802, 815-16 (8th Cir. 2011) (relying on Wal-Mart, and concluding that commonality was not satisfied in case brought by AfricanAmerican employees alleging race discrimination under Title VII because they did not "demonstrate that the employer had a policy of allowing discretion by lower-level supervisors over employment matters" and "that all supervisors "exercise[d] their discretion in a common way"); see also Ellis v. Costco Wholesale Corp., 657 F.3d 970, 980-85, 988 (9th Cir. 2011) (relying on Wal-Mart, vacating and remanding the lower court's decision to certify a class of current and former employees for failure to meet the commonality and typicality standards).

291. McReynolds, 672 F.3d at 489, 492.

292. Scott v. Family Dollar Stores, Inc., 733 F.3d 105, 114, 119 (4th Cir. 2013).

293. McReynolds, 672 F.3d at 490.

294. Scott, 733 F.3d at 114 .

295. For purposes of this article, the author does not weigh in on whether the record supports this conclusion. Taking as true, arguendo, the Court's conclusion that power was decentralized at WalMart, this was a policy choice the corporation made that does not warrant different certification treatment.

296. This, of course, is contextual. Whether personnel are prone to bias may be, in part, 
justification for treating one employer's policy choice differently than another, for purposes of class certification.

Granted, supervisors in the field untethered from corporate oversight could lead to rogue actors and behaviors. This would certainly be relevant to whether there was a pattern or practice of discrimination. But equally relevant would be whether a company intentionally crafted a personnel scheme with minimal corporate participation and oversight, and knowingly turned a blind eye to the consequential discriminatory practices of its subordinates. Also relevant is the extent to which such employment decisions operated in an environment that allegedly institutionalized gender inequality and power inequities.

While Wal-Mart has not sounded the death knell for employment discrimination and civil rights class actions-including those alleging discretionary behavior - the ruling has front-loaded and elevated the merits inquiry at the class certification stage. The expense and time involved in merits discovery for all parties at the class certification stage warrant concern. The hidden cost of front-loading such discovery may deter potentially meritorious cases from being brought. Indeed, fewer employment discrimination class actions, for example, have already been filed post-Wal-Mart. ${ }^{297}$

\section{Contractual Rights Over Civil Rights: The Enforcement of Class Arbitration Bans}

Given the seminal role of aggregate litigation in eradicating systemic discrimination, one of the most troubling trends of modern civil litigation is the privatization of the justice system. ${ }^{298}$ This is because for dispute resolution systems outside of the public domain - such as pre-dispute compulsory arbitration-there are often less procedural protections for workers, consumers and every-day litigants. ${ }^{299}$ Examples of such waived protections include the right to a jury trial, subsidized forum, transparent process, written record, robust discovery, binding legal precedent and significant appellate review. ${ }^{300}$ Remedies may be proscribed, precedent

environmentally based. In Wal-Mart, plaintiffs argued that the risk of bias was significant because of the corporate culture. Wal-Mart Stores, Inc. v. Dukes, 564 U.S. 338, 345 (2011).

297. See Selmi \& Tsakos, supra note 270, at 804, 804 n.5.

298. See generally Suzette M. Malveaux, Is It the "Real Thing”? How Coke's One-Way Binding Arbitration May Bridge the Divide Between Litigation and Arbitration, 2009 J. DISP. RESOL. 77 (2009) [hereinafter Malveaux, Is It the Real Thing?].

299. Id. at 80-81, 83-85.

300. Id. at 84 . 
jettisoned and arbitrators' neutrality compromised. ${ }^{301}$

Having said that, arbitration may offer advantages that the court system does not. It may include lower costs, greater speed, more flexibility in process and remedy, enhanced privacy and a decision-maker with superior subject-matter expertise. ${ }^{302}$

Given the considerable distinctions between private arbitration and the public litigation system, one would expect the presence of significant safeguards to ensure that parties knowingly consent to one forum over another. To the contrary, many individuals with little or no bargaining power are compelled to forego their "day in court" because they unknowingly signed an arbitration clause appearing in fine print, buried in a contract, written in incomprehensible legalese. ${ }^{303}$ The bulwarks of freedom of contract - such as a meeting of the minds and consentquickly break down in this environment, thereby undermining familiar justifications for the enforcement of such arbitration agreements.

Over the last several decades, ${ }^{304}$ and more acutely under the Roberts Court, the Supreme Court has trended toward enforcement of private arbitration agreements. ${ }^{305}$ This deference has resulted in a proliferation of arbitration agreements in all manner of contract, including employment. ${ }^{306}$ Emboldened by this jurisprudence, by 2007 , employers had contracted with twenty percent of the workforce to waive court access for workplace disputes. ${ }^{307}$ A recent study indicates that "since the early 2000 s, the share of workers subject to mandatory arbitration has more than doubled and now exceeds 55 percent." $" 308$

301. Id. at $84-85$.

302. Id. at 84 . However, there are occasions when arbitration is more expensive than litigation given the hourly cost of an arbitrator and various fees.

303. Id. at 85 .

304. See id. at 80-83 (describing prevalence and evolution of pre-dispute compulsory arbitration agreements).

305. The latest example of this is Kindred Nursing Centers Limited Partnership v. Clark, in which the United States Supreme Court held that FAA was violated where state rule held that arbitration agreement was unenforceable because waiver of court access and jury trial was conditioned upon express provision in power-of-attorney. 137 S. Ct. 1421, 1425 (2017).

306. See Malveaux, Is It the Real Thing?, supra note 298 , at 83.

307. A 2007 study found that approximately one out of five employees are subject to arbitration. Alexander J.S. Colvin, Empirical Research on Employment Arbitration: Clarity Amidst the Sound and Fury?, 11 EMP. RTS. \& EMP. POL'Y J. 405, 411 (2007) (“Although there are limitations to the existing studies, they do show a consistent pattern of significant expansion of employment . . . a current estimate in the range of 15 to 25 percent of employers having adopted employment arbitration seems reasonable.").

308. AleXander J.S. Colvin, The Growing Use of Mandatory Arbitration; AcCess to THE COURT IS NOW BARRED FOR MORE THAN 60 MILLION AMERICAN WORKERS, ECON. POL'Y INST. 1 (2017), http://www.epi.org/files/pdf/135056.pdf. The study also found that more than half of nonunion private-sector employers have mandatory arbitration. $I d$. at 1-2. This number goes over 
Not only is significant employment in the United States conditioned on waiver of court access, employment is increasingly conditioned on waiver of collective action. Fueled by favorable jurisprudence, a growing number of businesses are inserting class action bans in arbitration agreements embedded in their employment contracts. ${ }^{309}$ For example, from 2012 to 2015 , class arbitration bans increased from $16.1 \%$ to $39.2 \% .{ }^{310}$ A recent study found that, of employees subjected to mandatory arbitration, over $41 \%$ have signed a class action waiver. ${ }^{311}$ This results in over $23 \%$ of private-sector nonunion employees-24.7 million American workers - not permitted to bring a class action for employment claims. ${ }^{312}$ Consequently, employees seeking to challenge discriminatory personnel practices through negative value suits are foreclosed from doing so outside the class action paradigm.

The Court's key rulings have enabled this trend. ${ }^{313}$ For example, in AT\&T Mobility LLC v. Concepcion, the Court upheld the enforceability of a class arbitration ban despite California's judicial rule that certain bans were unconscionable. ${ }^{314}$ The Court concluded that California's law was inconsistent with the Federal Arbitration Act (FAA) and pre-empted by the Act. ${ }^{315}$ California could not condition the enforceability of an arbitration agreement on the availability of a class action. ${ }^{316}$ Concepcion established this prohibition despite the American Arbitration Association's history of successful class arbitrations, the admitted importance of aggregation to small dollar claims, and the application of California's class action ban to arbitration and litigation alike. ${ }^{317}$

Similarly, in American Express v. Italian Colors Restaurant, the Court upheld an arbitration agreement that foreclosed aggregation but went even

\footnotetext{
$65 \%$ for companies larger than 1,000 employees. Id. For private-sector non-union employees, over $56 \%$ are subject to mandatory arbitration. Id. at 2. Consequently, the study concludes that for the overall workforce, over 60 million American workers are subject to arbitration. Id. at 5 .

309. See id. at $1-2$.

310. Julianna Thomas McCabe, SCOTUS to Determine Enforceability of Class Action Waivers in Employment Contract Arbitration Clauses, Classified: The Class ACTION Blog (Jan. 13, 2017), http://classifiedclassaction.com/scotus-determine-enforceability-class-action-waivers-employ ment-contract-arbitration-clauses/.

311. Colvin, supra note 307 , at 2.

312. Id.

313. Am. Express Co. v. Italian Colors Rest., 133 S. Ct. 2304, 2313 (2013) (Kagan, J., dissenting).

314. 563 U.S. $333,351-52(2011)$.

315. Id. at 352 .

316. Id. at 344 .

317. The Supreme Court again held that California law was pre-empted by the FAA because the state court allegedly interpreted arbitration agreements with class actions bans less favorably than other contracts. See DIRECTV, Inc. v. Imburgia, 136 S. Ct. 463, 471 (2015).
} 
farther. $^{318}$ In this antitrust case, the Court concluded that even if a proposed class of merchant plaintiffs proves that it is economically impossible to individually pursue their cases in arbitration, an arbitration agreement that forbids them from seeking a class action is enforceable under the FAA. ${ }^{319}$ Pursuant to the agreement's terms, a party is compelled to pursue its claim individually-regardless of whether individual arbitration is impossible or irrational to pursue. ${ }^{320}$ In this case, the cost of an expert analysis necessary to prove the merchants' claims far exceeded each individual's potential recovery (some by ten times). ${ }^{321}$ Thus, in the absence of any cost-sharing with the defendant, aggregation was the only viable way to challenge defendant's business practices. ${ }^{322}$

The Court has articulated a commitment to arbitration subject to the forum's being an effective vehicle for rights vindication. ${ }^{323}$ The effective vindication rule, however, has been significantly eroded by American Express. The Court's prioritization of the existence of rights in theory over practice ${ }^{324}$ allows arbitration to be used as a shield for corporate malfeasance and accountability. This misappropriation delegitimizes the significant value of this litigation alternative and unfortunately risks equating the forum with abusive practices and partiality.

The Court has the opportunity to rein in this misappropriation in Epic Systems Corp. v. Lewis. ${ }^{325}$ The Court recently granted review to determine whether an arbitration agreement between an employer and employee that waives Rule 23 class actions and FLSA collective proceedings for laborrelated claims is enforceable under the Federal Arbitration Act, notwithstanding the National Labor Relations Act's protection of an employee's right to engage in "concerted activities."

In this case, employee Jacob Lewis sued his employer, Epic Systems Corp., in federal court on behalf of himself and other technical writers, alleging that Epic violated the FLSA and Wisconsin law by misclassifying

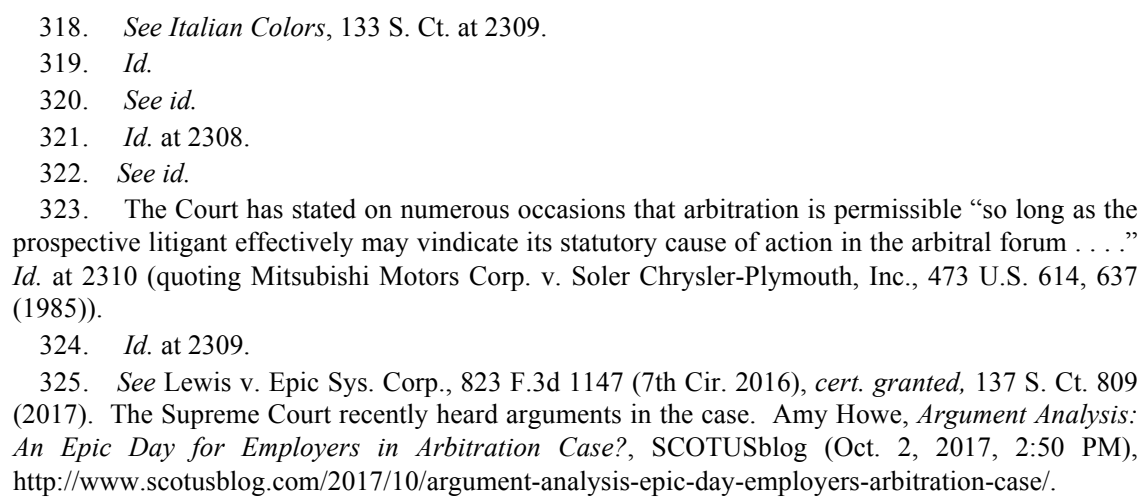
prospective litigant effectively may vindicate its statutory cause of action in the arbitral forum ...." Id. at 2310 (quoting Mitsubishi Motors Corp. v. Soler Chrysler-Plymouth, Inc., 473 U.S. 614, 637 (1985)).

324. Id. at 2309 .

325. See Lewis v. Epic Sys. Corp., 823 F.3d 1147 (7th Cir. 2016), cert. granted, 137 S. Ct. 809 (2017). The Supreme Court recently heard arguments in the case. Amy Howe, Argument Analysis: An Epic Day for Employers in Arbitration Case?, SCOTUSblog (Oct. 2, 2017, 2:50 PM), http://www.scotusblog.com/2017/10/argument-analysis-epic-day-employers-arbitration-case/. 
them and unlawfully denying them overtime pay. ${ }^{326}$ Epic moved to dismiss the complaint and compel individual arbitration pursuant to an arbitration agreement prohibiting class and collective actions in the adhesion employment contract.

The courts below concluded that the class arbitration waiver violated the NLRA's Section 7, which gives employees the right to "engage in ... concerted activities for the purpose of . . . mutual aid or protection," and Section 8, which enables them to enforce that right. ${ }^{327}$ Moreover, the Seventh Circuit held the arbitration agreement unenforceable under the Federal Arbitration Act's "savings clause" because the agreement violated "generally applicable contract defenses." "28 More specifically, the arbitration agreement is allegedly unenforceable under the FAA because it violates the NLRA. ${ }^{329}$

The propriety of class action bans in employment arbitration agreements has come to a head, with the circuit courts split on the issue. ${ }^{330}$ This is the question the Supreme Court seeks to resolve.

At risk is that arbitration agreements will effectively become exculpatory clauses. Workers will be compelled to forgo their rights in exchange for employment through boilerplate adhesion contracts that disallow class arbitration and make individual arbitration cost-prohibitive. Thus, workers who have discrimination and fair wage claims that arise in the course of their employment may not be able to effectively challenge systemic misconduct, especially where their claims and wages are small. This capture of the arbitral forum does harm to the procedural vehicle itself and does a disservice to those individuals seeking to use the civil rights provision of the modern class action rule as intended. ${ }^{331}$ The outcome will be less enforcement in the cases where it is needed the most. And given the likelihood that the enforcement gap cannot be effectively filled by relevant government agencies, the rule of law is endangered.

\footnotetext{
326. See id. at 1151.

327. Id. at 1155 (citing 29 U.S.C. $\$ 157$ (2012)).

328. Id. at 1156 (an arbitration agreement "shall be valid, irrevocable, and enforceable, save upon such grounds as exist at law or in equity for the revocation of any contract" (quoting 9 U.S.C. $\S 2$ (2012))).

329. Id. at $1156-57$.

330. The Seventh and Ninth Circuits have concluded that such class action waivers are unenforceable because of their interference with the NLRA. See e.g., id.; NLRB v. Stone, 125 F.2d 752, 756 (7th Cir. 1942); Morris v. Ernst \& Young LLP, 834 F.3d 975, 990 (9th Cir. 2016), cert. granted, 137 S. Ct. 809 (2017). The Second, Fifth, and Eighth Circuits disagree. Cellular Sales of Missouri, LLC v. N.L.R.B., 824 F.3d 772, 776 (8th Cir. 2016); Murphy Oil USA, Inc. v. N.L.R.B., 808 F.3d 1013, 1015 (5th Cir. 2015); Sutherland v. Ernst \& Young LLP, 726 F.3d 290, 297 n.8 (2d Cir. 2013).

331. See Marcus, History of the Modern Class Action, supra note 28, at 608.
} 
3. Statutory, Constitutional and Evidentiary Gateway Issues to

Collective Litigation

The recent direction of aggregation jurisprudence has proven more nuanced as parties on both sides jockey to define how wide the door should be for access to representative litigation. The parameters of the federal procedural rules, the Constitution, and evidentiary proof are the latest battleground upon which plaintiffs and defendants vie for influence. The Court's response has been mixed.

\section{a. Gamesmanship}

Two recent opinions by former Civil Procedure Professor, now Supreme Court Justice, Ginsburg illustrate the Court's intolerance for perceived gamesmanship on both sides. On the one hand, the Court has rejected defendants' manufacturing mootness of putative class actions by paying off named plaintiffs' individual claims. On the other hand, the Court has rejected plaintiffs' circumventing the discretionary interlocutory appellate process for certification denials by voluntarily dismissing their individual cases. The Court's rulings have identified the envelope's edge as both the defense and plaintiffs' bar attempt strategies that promote the interests of their client base.

Plaintiffs may take some solace in the Court's treatment of defendants' offers of judgment and settlement made to named plaintiffs to moot putative class actions. The impact of such offers on the viability of potential aggregation has evolved in plaintiffs' favor.

Initially, in Genesis Healthcare Corp. v. Symczyk, the Court held that a collective action under the Fair Labor Standards Act (FLSA) became moot when, before moving for conditional class certification and before any plaintiffs opted-in, the named plaintiff received an offer of judgment under Rule 68 that would fully resolve all of her claims. ${ }^{332}$ Where the sole named plaintiff received an offer-which was unaccepted - that mooted her FLSA claim, the collective action was also mooted. ${ }^{333}$ Thus, an employer at risk of significant class-wide liability could strategically avoid such potential exposure by offering the individual class representative complete relief upfront.

However, in Campbell-Ewald Co. v. Gomez, the Court later

\footnotetext{
332. 569 U.S. 66, 69-71, 78-79 (2013).

333. See id. at 78. The Supreme Court did not decide whether a Rule 68 offer of judgment could moot an individual case, but rather presumed this. $I d$.
} 
disallowed a company to defeat class certification by making a complete Rule 68 offer of judgment or settlement offer-which was unacceptedto the individual putative class representative. ${ }^{334}$ Gomez adopted the rationale of Justice Kagan's dissent in Symczyk, noting that as most firstyear law students are taught, an unaccepted offer has no legal consequence. ${ }^{335}$ This plaintiff victory, however, may be tempered by what the Court did not decide: "We need not, and do not, now decide whether the result would be different if a defendant deposits the full amount of the plaintiff's individual claim in an account payable to the plaintiff, and the court then enters judgment for the plaintiff in that amount." 336

This open question foreshadows mootness issues to come, as evidenced already in the courts below. ${ }^{337}$ At this juncture, however, those seeking to challenge systemic discrimination under the refuge of the modern class action rule need not fear that this defense tactic will diminish the scope of their case.

Alternatively, defendants may take some solace in the Court's treatment of plaintiffs' use of voluntary dismissals to immediately challenge certification denials. In Microsoft Corp. v. Baker, owners of Microsoft's Xbox 360 videogame console filed a putative class action alleging a design defect. ${ }^{338}$ The district court struck plaintiffs' class allegations from the complaint, resulting in plaintiffs' seeking the Ninth Circuit's permission to immediately appeal the certification denial pursuant to Rule 23(f). ${ }^{339}$ When the appellate court exercised its discretion in plaintiffs' disfavor, they voluntarily dismissed their individual claims with prejudice, but reserved the right to resurrect them if the appellate court reversed the lower court's certification denial. ${ }^{340}$

Armed with what they thought was a final decision, the plaintiffs appealed only the Ninth Circuit's decision to strike their class allegations. ${ }^{341}$ The Ninth Circuit concluded that it had jurisdiction under 28 U.S.C. $\S 1291$ - which empowers the appellate court to review only "final decisions of the district courts"-and reversed the lower court's

\footnotetext{
334. 136 S. Ct. 663, 666-68, 671-72 (2016).

335. Id. at 670; Symczyk, 569 U.S. at 81 (Kagan, J., dissenting) (“As every first-year law student learns, the recipient's rejection of an offer 'leaves the matter as if no offer had ever been made."'). 
decision to strike the class claims. ${ }^{342}$

Upon Microsoft's challenge to the appellate court's jurisdiction, the Supreme Court held that the Ninth Circuit lacked $\S 1291$ jurisdiction because plaintiffs' voluntary-dismissal decision was not a final decision, but rather a tactic to circumvent Rule 23(f)'s discretionary interlocutory review of certification denials. ${ }^{343}$ The Court rejected this tactic not only because it appeared to be a work-around discretionary review - and thus a rebuke of the courts' roles in relation to each other and the rulemaking process $^{344}$ - but that it also unfairly favored plaintiffs over defendants. ${ }^{345}$ As in Gomez, Justice Ginsburg rejected what she perceived as "one-sided" gamesmanship too close to the line. Consequently, those defending themselves from allegations of class-wide discrimination need not fear that certification denials can be immediately appealed solely at the plaintiffs' discretion. ${ }^{346}$ In sum, for plaintiffs and defendants alike, the current Court is not only in the business of safeguarding legal boundaries, but also of policing aggregate litigation strategies when they flout more prudential lines.

b. Standing

Another issue for those seeking to redress systemic discrimination via aggregation is the extent to which the Court may cabin or broaden the standing doctrine for named plaintiffs and putative class members. Standing has increasingly become a gateway issue for class actions, with both plaintiff and defense counsel poised to do battle and declare victory. $^{347}$

On the defense side, litigants contend that there has been a proliferation of class actions filed by named plaintiffs who are uninjured

\footnotetext{
342. Id.

343. Id. at 1715; see id. at 1712 ("Because respondents' dismissal device subverts the finaljudgment rule and the process Congress has established for refining that rule and for determining when nonfinal orders may be immediately appealed . . . the tactic does not give rise to a 'final decisio[n]' under § 1291.”).

344. Id. at $1714-15$.

345. Id. at 1715. The Court referred to the voluntary-dismissal device as "one-sided" and noted that "[r]espondents' theory permits plaintiffs only, never defendants, to force an immediate appeal of an adverse certification ruling." Id. Moreover, the voluntary-dismissal device works against "Rule 23(f)'s evenhanded prescription." Id.

346. Id. at $1708,1715$.

347. See Perry Cooper, Both Sides Claim Victory in Statutory Injury SCOTUS Case, 84 U.S.L.W. 1688 (2016), https://www.bna.com/sides-claim-victory-n57982072511/ ("Both sides claimed victory from the U.S. Supreme Court's holding in a closely watched statutory violation suit May 16, that plaintiffs must show concrete - but not necessarily tangible — injury to access the federal courts.").
} 
and therefore ineligible to bring systemic statutory cases for want of Article III standing. The argument goes that even where there is a violation of the underlying statute, this is insufficient to confer standing if there has not been a concomitant injury-in-fact. To allow otherwise would give Congress the power to expand court jurisdiction beyond the Constitution's limitations. Moreover, the defense contends that a proliferation of such class actions will unjustly enrich plaintiffs' counsel and clog the court system with frivolous litigation. ${ }^{348}$

On the plaintiff side, litigants argue against a heightened standing requirement. They contend that when entities willfully violate someone's statutory rights, this should be sufficient to confer him standing. ${ }^{349}$ Where Congress has created a private right of action to enforce a statutory provision, it follows that a violation of that provision satisfies the injuryin-fact prerequisite. Otherwise, plaintiffs would not have access to the courts to enforce a host of federal statutes, including anti-discrimination ones. $^{350}$

With the courts divided on this standing doctrine, ${ }^{351}$ the Supreme Court has forayed into the area with mixed results. Its initial attempt in First American Financial Corporation v. Edwards was lack luster, resulting in the conclusion that the case had been improvidently granted. ${ }^{352}$ The Court's more recent attempt, Spokeo Inc. v. Robins, while ultimately remanding the question of standing to the lower court, has established a more nuanced approach than either party embraced. ${ }^{353}$

348. Marcia Coyle, Justices Weigh Concrete Injuries in a Digital Age, SUPREME COURT BRIEF (Nov. 2, 2015), https://www.law.com/supremecourtbrief/almID/1202741409084/.

349. A similar rationale justifies nominal damages for procedural violations that do not result in actual injury. See Carey v. Piphus, 435 U.S. 247, 248, 254-67 (1978) (holding that where there was no proof of actual injury, students were only entitled to nominal damages for violation of Fourteenth Amendment procedural due process in 42 U.S.C. $\S 1983$ case).

350. Shari Claire Lewis, Standing to Assert Claims for Online Privacy Breaches; Internet Issues/Social Media, N.Y.L.J. (Dec. 15, 2015), http://www.newyorklawjournal.com/id=120274457 5078/Standing-to-Assert-Claims-for-Online-Privacy-Breaches?slreturn=20170904223524; Coyle, supra note 348. The Ninth Circuit analogized the statutory rights created by the FCRA to those created by civil rights statutes such as the Fair Housing Act (FHA), where a violation alone satisfies Article III standing. See Robins v. Spokeo, Inc., 742 F.3d 409, 412 (9th Cir. 2014), vacated, 136 S. Ct. 1540 (2016) (finding "an individual's personal interest in living in a racially integrated community" under the FHA suffices for Article III standing).

351. See Petition for a Writ of Certiorari at 9-12, Spokeo, Inc. v. Robins, 136 S. Ct. 1540 (2016) (No. 13-1339) (describing various court approaches over whether a statutory violation without a concrete injury satisfies Article III standing, although not finding a split for FCRA claims); Reply Brief for the Petitioner at 6-8, Spokeo, Inc., 136 S. Ct. 1540 (No. 13-1339) (describing lower court conflict as "genuine and deepening").

352. First Am. Fin. Corp. v. Edwards, 136 S. Ct. 1533 (2016).

353. Spokeo, Inc., 136 S. Ct. at 1550. 
In Spokeo Inc. v. Robins, the Court was tasked with determining in a putative class action whether the named plaintiff Robins had Article III standing to sue website operator Spokeo under the Fair Credit Reporting Act (FCRA) for willfully publishing inaccurate information about him. ${ }^{354}$ Despite Robins's contention that the false information impaired his ability to get a job, the district court dismissed the case for lack of subject matter jurisdiction. ${ }^{355}$ In particular, the district court held that Robins had alleged only a statutory violation, and not an injury-in-fact, thus depriving him of constitutional standing. ${ }^{356}$ The Ninth Circuit reversed, concluding that the alleged statutory violation was sufficient for Article III standing. ${ }^{357}$

The Supreme Court - in a much-awaited opinion - ultimately did not resolve the thorny question over the extent to which Congress has the power to determine what constitutes an injury sufficient to confer Article III standing. In a six-to-two opinion authored by Justice Alito, ${ }^{358}$ the Court concluded that in order to have constitutional standing, Robins needed to have suffered an "injury-in-fact," which meant that the injury was both "concrete and particularized." 359 The case was remanded because the Ninth Circuit had failed to do this. ${ }^{360}$ The Court made clear, however, that a "concrete" injury was not "necessarily synonymous with "tangible" and that "intangible injuries can nevertheless be concrete." " In fact, a "risk of real harm" may satisfy "concreteness." Congress has the power to elevate an intangible harm to a concrete injury, but a "bare procedural violation" is not enough to confer Article III standing. ${ }^{362}$ Although the dissent concluded that Robins had already alleged an actual injury, the majority did not-leaving this for the Ninth Circuit below. ${ }^{363}$

Spokeo permits named plaintiffs to collectively pursue claims under federal statutes-including civil rights-when they suffer intangible harms, so long as those harms are concrete. The fact that such harms are sufficient to confer constitutional standing advantages plaintiffs. ${ }^{364}$ That

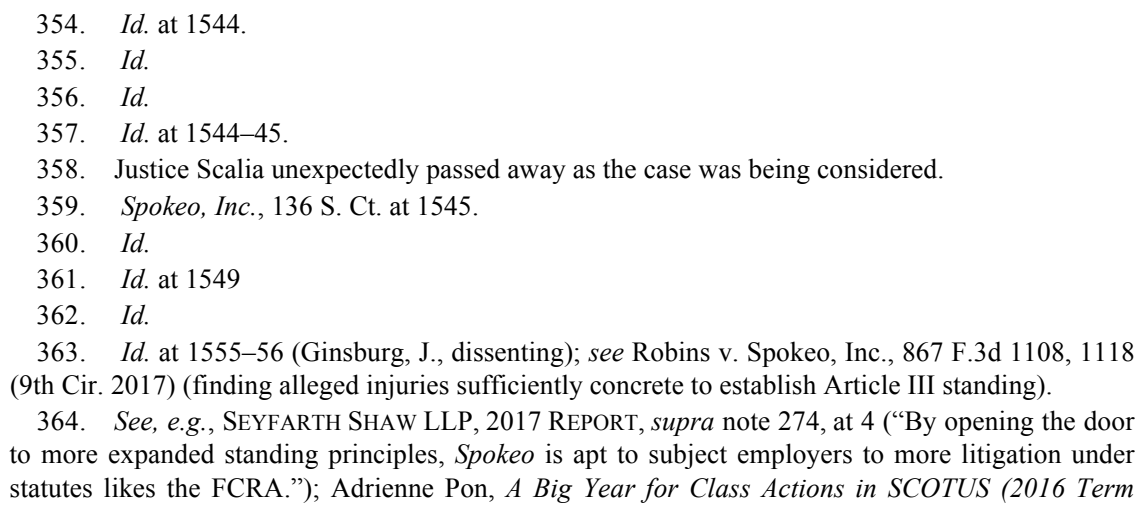


advantage is tempered, however, by whether plaintiffs will be able to successfully prove that their claims go beyond mere technical statutory violations.

Moreover, whether absent class members should each have to suffer an injury-in-fact, thereby giving them standing, is hotly contested. There is significant apprehension over the existence of "no-injury classes," of concern, inter alia, that such classes are bloated with non-injured individuals who will take from those with legitimate claims. This concern, however, should not matter for the traditional (b)(2) civil rights injunctive class action because of its focus on group harm and group remedy. There is no individuation, thereby making an injury-in-fact prerequisite for each absent class member purposeless.

This cannot be said for the (b)(3) class. Here, requiring standing to encompass not only a federal statutory violation, but also actual injuries, makes Rule 23(b)(3) class certification potentially less likely. Plaintiffs run the risk that individualized injury-in-fact determinations will predominate over the common question of a statutory violation, making (b)(3) certification impossible. ${ }^{366}$ Erecting this certification barrier may limit corporate exposure and deter plaintiffs from bringing aggregate litigation in all manner of cases involving federal statutory rights. ${ }^{367}$ As civil rights litigants pursuing monetary and injunctive relief post-WalMart are shunted from the traditional (b)(2) to (b)(3) class, the parameters of the latter become more salient.

Although it is premature to predict the impact of Spokeo, on balance, the Court's standing doctrine is more nimble and nuanced than expected. The contours of the standing doctrine are still very much being shaped, giving lower courts the opportunity to craft jurisprudence consistent with promoting court-access, law enforcement and Congressional restraint.

Similarly, Article III's case or controversy requirement is potentially another issue with far-reaching implications for the future of civil rights aggregate litigation. This justiciability requirement may be an entry point for courts' tamping down the extent to which named plaintiffs may represent class interests when their own individual claims have been

Review), IMPACT FUND (Aug. 18, 2016), https://www.impactfund.org/legal-practitionerblog/scotus16-classactions.

365. See, e.g., Kohen v. Pac. Inv. Mgmt. Co., 571 F.3d 672, 677 (7th Cir. 2009) (“[A] class should not be certified if it is apparent that it contains a great many persons who have suffered no injury at the hands of the defendant[.]" (citations omitted)).

366. See Cooper, supra note 347 (explaining that the question of whether a case may be certified as a class action where its absent class members are uninjured was not decided by Tyson Foods Inc. $v$. Bouaphakeo, 136 S. Ct. 1036 (2016), as anticipated.).

367. Lewis, supra note 350. 
extinguished.

The Court's recent Microsoft decision is instructive. This instruction comes in large part from what the Court did not decide. Tellingly, the majority opinion of five justices ${ }^{368}$ skirted the second question that was granted certiorari review: i.e., whether the federal appellate courts have jurisdiction under Article III of the Constitution to review a class certification denial after the named plaintiffs voluntarily dismissed their claims with prejudice. ${ }^{369}$ Relying on $\S 1291$ 's statutory jurisdictional grounds, the majority never reached the constitutional standing question squarely addressed by the concurrence. ${ }^{370}$

By contrast, Justice Thomas' concurring opinion adopted the judgment, but on constitutional grounds. ${ }^{371}$ More specifically, he concluded that the named plaintiffs' voluntary dismissal with prejudice constituted a final judgment, ${ }^{372}$ but that the Ninth Circuit still lacked jurisdiction because there was no "case" or "controversy" required by Article III. ${ }^{373}$ Plaintiffs' voluntary extinguishment of all of their individual claims left them "no longer adverse" to Microsoft "on any claims.", ${ }^{374}$ The concurrence narrowly defines the case-or-controversy justiciability requirement in the class action context:

Class allegations, without an underlying individual claim, do not give rise to a "case" or "controversy." Those allegations are simply the means of invoking a procedural mechanism that enables a plaintiff to litigate his individual claims on behalf of a class. Thus, because the Court of Appeals lacked Article III jurisdiction to adjudicate the individual claims, it could not hear the plaintiffs' appeal of the order striking their class allegations. ${ }^{375}$

This narrow justiciability interpretation-adopted by only three Justices $^{376}$ — bodes unwell for putative classes. Decoupling individual named plaintiffs from the putative class for case-or-controversy purposes would neuter the latter whenever the former's claims are resolved. This

\footnotetext{
368. Microsoft Corp. v. Baker, 137 S. Ct. 1702 (2017) (Justice Ginsburg authored the opinion, which was joined by Justices Kennedy, Breyer, Sotomayor and Kagan).

369. Id. at 1712 .

370. Id.

371. Id. at 1716 (Thomas, J., concurring). This was joined by Chief Justice Roberts and Justice Alito. Id. at 1715 (Thomas, J., concurring).

372. Id. at 1716 (Thomas, J., concurring).

373. Id. at 1717 (Thomas, J., concurring).

374. Id. (Thomas, J., concurring).

375. Id. at 1718 (Thomas, J., concurring) (emphasis added) (citation omitted).

376. They are Justice Thomas, Justice Alito and Chief Justice Roberts. Justice Gorsuch did not participate in the consideration or decision of the case.
} 
outcome seems unjustified given the Court's prior recognition that even a named plaintiff whose own individual claim is mooted may appeal a denial of class certification order. ${ }^{377}$ Not only the Court's precedent, but also its acknowledgement of the class action's separate role, warrants a broader justiciability stance. ${ }^{378}$

In sum, the Court's interpretation of constitutional gateway issuessuch as standing, mootness and the existence of a case-or-controversyforeshadows the types of challenges and feats those contesting systemic discrimination can expect going forward. The extent to which a named plaintiff has sufficient skin in the game to promote class interests is a continued debate that will have significant ramifications for civil rights enforcement.

\section{c. Ascertainability}

Another significant issue in aggregation jurisprudence is how rigorous courts should be in requiring litigants to be able to ascertain class membership as a condition of certification. The Circuit Courts of Appeals are divided not so much over the propriety of this implicit threshold itself - which is found nowhere in the class action rule - but over whether the threshold should be exacting or not. On the one hand, the Third Circuit, ${ }^{379}$ joined by the First, ${ }^{380}$ Fourth $^{381}$ and Eleventh ${ }^{382}$ Circuits have adopted a heightened ascertainability standard which requires that: 1) the class be "defined with reference to objective criteria" and 2) there is a "reliable and administratively feasible mechanism for determining whether putative class members fall within the class definition." 383 On the

377. See U.S. Parole Comm'n v. Geraghty, 445 U.S. 388, 404 (1980). This point was argued in Brief of Complex Litigation Law Professors as Amici Curiae in Support of Respondents at 16-17, Microsoft Corp. v. Baker, 137 S. Ct. 1702 (2017) (No. 15-457) ("The Geraghty Court concluded that the named party could appeal the denial of class certification despite his mooted claims because " $[\mathrm{t}] \mathrm{he}$ proposed representative retains a "personal stake" in obtaining class certification sufficient to assure that Art. III values are not undermined." (citing Geraghty, 445 U.S. at 404)).

378. See Brief of Complex Litigation Law Professors as Amici Curiae in Support of Respondents, supra note 377, at 24-25, of which I was a signatory; see also Sergio J. Campos, Class Actions and Justiciability, 66 FLA. L. REV. 553, 611-21 (2014).

379. See Byrd v. Aaron's Inc., 784 F.3d 154, 163 (3d Cir. 2015); Carrera v. Bayer Corp., 727 F.3d 300, 306-08 (3d Cir. 2013); Hayes v. Wal-Mart Stores, Inc., 725 F.3d 349, 355 (3d Cir. 2013); Marcus v. BMW of N. Am. LLC, 687 F.3d 583, 592-94 (3d Cir. 2012).

380. In re Nexium Antitrust Litig., 777 F.3d 9, 19 (1st Cir. 2015).

381. EQT Prod. Co. v. Adair, 764 F.3d 347, 358 (4th Cir. 2014).

382. Karhu v. Vital Pharms. Inc., 621 F. App'x 945, 946 (11th Cir. 2015).

383. See Byrd, 784 F.3d at 163 (quoting Hayes, 725 F.3d at 355). See also Marcus, 687 F.3d at 593 ("If class members are impossible to identify without extensive and individualized fact-finding or 'mini-trials,' then a class action is inappropriate."). 
other hand, the Seventh, joined by the Second, Sixth, Eighth and Ninth Circuits have rejected the second "administrative feasibility" prong. ${ }^{384}$

Competing rationales are behind the dueling approaches. Those supporting heightened ascertainability rely on a number of arguments set forth by the leading Third Circuit case, Carrera. ${ }^{385}$ First, the approach eliminates administrative burdens - such as mini-trials - just to identify class members, which supports the efficiency goal of aggregate litigation. ${ }^{386}$ Second, rigorous ascertainability ensures proper notice to the class. ${ }^{387}$ Third, the heightened approach screens out illegitimate claimants whose participation dilutes recovery for legitimate claimants. ${ }^{388}$ Finally, the rigorous bar is necessary to protect defendants' due process rights to raise individual defenses and challenge individual class membership. ${ }^{389}$

Those supporting ascertainability-lite, including most recently the Ninth Circuit, have countered each of the above rationales. ${ }^{390}$ First, an administrative feasibility requirement is not necessary given the class action rule's own manageability requirement, which effectively promotes efficiency. ${ }^{391}$ By contrast, there is nothing in the rule's text requiring administrative feasibility. To import this new standard runs counter to the Court's admonition against such impermissible rulemaking. Second, a heightened ascertainability requirement is not necessary for notice because the rule requires only the "best notice that is practicable under the circumstances," rather than actual notice. ${ }^{392}$ Third, given the low response rate to class settlements, the concern over fraudulent submissions is not

384. Mullins v. Direct Dig. LLC, 795 F.3d 654, 657-58 (7th Cir. 2015). The Second Circuit more recently clarified that it did not adopt the heightened ascertainability requirement. In re Petrobras Sec., 862 F.3d 250, 265 (2d Cir. 2017) ("With all due respect to our colleagues on the Third Circuit, we decline to adopt a heightened ascertainability theory that requires a showing of administrative feasibility at the class certification stage.”). See also Briseno v. ConAgra Foods Inc., 844 F.3d 1121, 1123 (9th Cir. 2017), cert. denied, 2017 U.S. LEXIS 6249 (Oct. 10, 2017); Sandusky Wellness Ctr. LLC v. Medtox Sci. Inc., 821 F.3d 992, 996 (8th Cir. 2016);See also Rikos v. Proctor \& Gamble Co., 799 F.3d 497, 525 (6th Cir. 2015), cert. denied, 136 S. Ct. 1493 (2016).

385. See Carrera v. Bayer Corp., 727 F.3d 300, 305-08 (3d Cir. 2013).

386. Id. at 305 .

387. Id. at $305-06$

388. Id. at 310 .

389. Id. at 307.

390. See Briseno v. ConAgra Foods, Inc., 844 F.3d 1121, 1123-33 (9th Cir. 2017); Robert G. Bone, Justifying Class Action Limits: Parsing the Debates Over Ascertainability and Cy Pres, $65 \mathrm{U}$. KAN. L. REV. 913, 928-40 (2017) [hereinafter Bone, Justifying Class Action Limits] (making arguments against rationales given for strict ascertainability and noting that "[a] class can exist without anyone knowing precisely who is and who is not a member").

391. See FeD. R. Civ. P. 23(b)(3); Bone, Justifying Class Action Limits, supra note 390, at 93335.

392. FED. R. CIV. P. 23(c)(2)(B); Bone, Justifying Class Action Limits, supra note 390, at 93031. 
significant. ${ }^{393}$ Finally, a defendant's due process rights are not implicated by the ascertainability threshold because the defendant can still raise individual affirmative defenses and challenges to the named plaintiffs immediately and to the absent class members later. ${ }^{394}$ Not surprisingly, the rigorous ascertainability hurdle is favored by the defense-especially for low-dollar claims - and the lite one favored by plaintiffs. ${ }^{395}$

While there is a "growing consensus" among the federal circuits in favor of ascertainability-lite, ${ }^{396}$ and some disagreement over just how split the circuit courts are ${ }^{397}$ there remains at least a clear demarcation in approach between the Third Circuit and others, which would countenance Supreme Court intervention. ${ }^{398}$ The Court, however, has declined review in Mullins v. Direct Digital LLC, ${ }^{399}$ Rikos v. Proctor \& Gamble Co., ${ }^{400}$ and Briseno v. ConAgra Foods, Inc. ${ }^{401}$

The duel between heightened and lite ascertainability, however, is one largely appropriate in the context of class actions certified pursuant to Rule 23(b)(3). ${ }^{402}$ Granted, as civil rights cases seeking monetary relief in addition to injunctive relief get shunted from Rule 23(b)(2) to (b)(3) postWal-Mart, this ascertainability threshold battle will increasingly matter. However, civil rights class actions seeking primarily injunctive relief-in which 23(b)(2) certification is appropriate-should as a normative matter be immune from any heightened ascertainability requirement given their fundamental history and role.

Conditioning certification on the ascertainability of class members should not apply to Rule 23(b)(2) classes because it is immaterial whether individual class members can be identified. ${ }^{403}$ The 1966 drafters made

\footnotetext{
393. See also Bone, Justifying Class Action Limits, supra note 390, at 935-37 (discussing distribution of class recovery).

394. See id. at 937-39.

395. See Amanda R. Lawrence, The Great Class Action Ascertainability Debate, LAw360 (Aug. 14, $2017 \quad 12: 47 \quad \mathrm{PM}), \quad$ https://www.law360.com/articles/953496/the-great-class-actionascertainability-debate; Chad R. Fuller et al., A Serious Circuit Split on Class Ascertainability, LAW360 (June 30, 2016 4:42 PM), https://www.law360.com/articles/813021/a-serious-circuit-spliton-class-ascertainability.

396. See In re Pertrobas Secs., 862 F.3d 250, 265 (2d Cir. 2017).

397. See Alison Frankel, SCOTUS Case Will Test Justice Gorsuch's Appetite for Class Action Limits, REUTERS (May 8, 2017), https://www.reuters.com/article/otc-gorsuch-idUSKBN18424X.

398. See id.

399. 795 F.3d 654 (7th Cir. 2015), cert. denied, 136 S. Ct. 1161 (2016).

400. 799 F.3d 497 (6th Cir. 2015), cert. denied, 136 S. Ct. 1493 (2016).

401. 844 F.3d 1121 (9th Cir. 2017), cert denied, 2017 U.S. LEXIS 6249 (Oct. 10, 2017).

402. Bone, Justifying Class Action Limits, supra note 390, at 957 ("[E]ven the strongest advocates of strict ascertainability refuse to apply it to (b)(2) class actions.").

403. See Larkin Letter, supra note 281, at 3; see, e.g., Cole v. City of Memphis, 839 F.3d 530, 542 (6th Cir. 2016); Shelton v. Bledsoe, 775 F.3d 554, 557-59, 561, 563 (3d Cir. 2015).
} 
clear that (b)(2) applies "in the civil-rights field where a party is charged with discriminating unlawfully against a class, usually one whose members are incapable of specific enumeration." 404 The goal of the civil rights class action provision is to provide a group remedy for group harm. The very nature of the harm is group-directed. ${ }^{405}$ The very nature of the remedy is indivisible, thereby making it unimportant for each individual class member to be ascertained. Each class member, by virtue of group membership, will be the beneficiary of the injunctive and/or declaratory relief.

Moreover, from a pragmatic vantage, heightened ascertainability for (b)(2) classes is unwarranted because class members are not entitled to notice or an opportunity to opt out of the collective litigation. ${ }^{406}$ Unlike (b)(3), there is no practical need to identify and inform individual class members of the litigation so that they can participate personally or withdraw altogether. ${ }^{407}$

The majority of federal appellate courts recognizes these distinctive features of the civil rights injunctive class and consequently do not hold it to a heightened ascertainability standard. Four circuits - including the most taxing Third Circuit ${ }^{408}$ - have explicitly ruled that ascertainability for (b)(2) classes is unnecessary. ${ }^{409}$ Despite such favorable jurisprudence for civil rights litigants challenging systemic discrimination, the direction of this gateway jurisprudence is unclear. Should the Court ultimately weigh in on the propriety of a more rigorous ascertainability requirement, the Court should recall the rulemakers' goal to protect and enhance collective actions against discrimination.

\section{d. Aggregate Proof}

Finally, a critical key to class action litigation is to what extent aggregate proof may be used for certification and class-wide liability. In Wal-Mart, Justice Scalia rejected the plaintiffs' proposal to replace

\footnotetext{
404. FED. R. CIV. P. 23(b)(2) advisory committee's notes to 1966 amendment. The Advisory Committee explained: "Action or inaction is directed to a class within the meaning of this subdivision even if it has taken effect or is threatened only as to one or a few members of the class, provided it is based on grounds which have general application to the class." Id.

405. FED. R. CIV. P. 23(b)(2)

406. Bone, Justifying Class Action Limits, supra note 390, at 930-31.

407. Cole, 839 F.3d at 541 .

408. Bone, Justifying Class Action Limits, supra note 390, at 929 (citing Shelton, 775 F.3d at 559-63) ("Yet even the Third Circuit, the strongest proponent of a strict ascertainability rule, declines to apply it to class actions certified under Rule 23(b)(2).").

409. Id.
} 
individualized back pay determinations following a pattern or practice finding with a sampling method, condemning it as "Trial By Formula." The Court concluded that plaintiffs' "novel project" would violate the employer's right to raise individual defenses under Title VII. ${ }^{411}$ Thus, it logically followed that such individualized back pay determinations were not "incidental" to the injunctive relief sought, making (b)(2) certification unjustified. ${ }^{412}$ In Comcast Inc. v. Behrend, ${ }^{413}$ the Supreme Court denied class certification in an antitrust case where plaintiffs' regression model failed to demonstrate that damages were susceptible to class-wide proof. ${ }^{414}$ Because of such failure, individual questions predominated over the common ones, making Rule 23(b)(3) certification inappropriate. ${ }^{415}$ Following Wal-Mart and Comcast, the notion that class certification is unjustified where monetary relief has to be calculated on an individualized basis has gained traction.

Tyson Foods, Inc. v. Bouaphakeo, a six-to-two decision by Justice Kennedy, however, has more recently tempered this impression. ${ }^{416}$ Tyson Foods allowed aggregate proof or sampling, to prove class-wide liability in a class action, despite Wal-Mart's language forbidding "Trial By Formula." ${ }^{417}$ In Tyson Foods, representative proof was permitted where the underlying substantive law-the Fair Labor Standards Act-allowed it. ${ }^{418}$ In particular, the Court permitted the use of a study reporting the average amount of time it took for an employee to don and doff his clothing at defendant's plant, especially where the employer failed to keep records. ${ }^{419}$ Tyson Foods also rejected the contention that a class cannot be certified if it requires individual damages calculations under Rule 23(b)(3) - contrary to how some have interpreted Comcast. ${ }^{420}$ Individualized damages are permissible, so long as they do not predominate under Rule 23(b)(3). While Tyson Foods cleared the way for

\footnotetext{
410. 564 U.S. 338, 366-67 (2011).

411. Id. at 367.

412. Id.

413. 569 U.S. 27 (2013).

414. Id. at 36-38. Plaintiffs' damages model suffered by not matching the theory of liability being pursued. $I d$.

415. See id.

416. 136 S. Ct. 1036 (2016).

417. Id. at 1046-48. The Court relied in part on Brief of Amicus Curiae Complex Litigation Law Professors in Support of Respondents, Tyson Foods, Inc. v. Bouaphakeo, 136 S. Ct. 1036 (2016) (No. 14-1146), of which I was a signatory.

418. Id. at 1042 .

419. Id. at 1047 .

420. See id. at 1053, 1056-57 (Thomas, J., dissenting) (discussing Comcast Corp. v. Behrend, 133 S. Ct. 1426, 1433 (2013)).
} 
a representative or statistical sample to be used in establishing class-wide liability, Justice Kennedy's ruling was narrow: its use "will depend on the purpose for the sample is being introduced and on the underlying cause of action." ${ }^{421}$ Again, the Court's latest word on the matter has left no clear victors.

In sum, the renewed jurisprudential interest in the modern aggregation rule has led to mixed results for litigants trying to use the class action to contest systemic discrimination. On the one hand, named plaintiffs have successfully staved off dismissal because of unaccepted offers of judgment or settlement. They may still challenge certain discretionary practices as discriminatory, forum shop, and structure the parameters of litigation such that certification is more likely. They continue to represent others, even when their own claims are resolved, and to use aggregate proof when defendants do not keep records.

On the other hand, litigants alleging discrimination have a far more formidable evidentiary task of proving commonality in systemic discrimination cases. For cases mirroring Wal-Mart's theory of liability, decentralized decision-making and size, this task is all but impossible. Moreover, plaintiffs are largely foreclosed from seeking monetary relief under the class action rule's civil rights provision, resulting in greater cost and risk to successfully aggregate their claims. Named plaintiffs are no longer able to immediately challenge a class certification denial by voluntarily dismissing their claims with prejudice or to represent a class without having an actual injury. Meanwhile, the Court's robust procedural docket continues to grow-with the addition of a new Justice as well ${ }^{422}$ leaving the landscape yet still subject to contour. ${ }^{423}$

421. Id. at 1049 .

422. See Ron Chapman Jr. \& Christopher Murray, Gorsuch and the Future of Class Action Waivers, LAW360 (Feb. 1, 2017, 1:28 PM), https://www.law360.com/articles/887293/gorsuch-andthe-future-of-class-action-waivers; Jeremy M. Creelan, Class Certification: Will Gorsuch Pick Up Where Scalia Left Off?, N.Y. L.J. (Feb. 14, 2017), http://www.newyorklawjournal.com/ id=1202779162473/Class-Certification-Will-Gorsuch-Pick-Up-Where-Scalia-Left-Off?slreturn= 20170909132830; Frankel, supra note 397 (describing Justice Gorsuch's first majority opinion).

423. This evolving jurisprudence is taking place before a backdrop of Congressional effort to resurrect proposals recently rejected or tabled by the Rule 23 Subcommittee and Advisory Committee. Compare Fairness in Class Action Litigation and Furthering Asbestos Claim Transparency Act of 2017, H.R. 985, 115th Cong. with REPORT OF THE JUdiCIAL CONFERENCE COMMITTEE ON RULES OF PRACTICE AND PROCEDURE 25-27 (summary of Rule 23 proposed amendments), App'x C-8-C-29 (red-lined Rule 23 with Advisory Committee Notes) (Sept. 2017) [hereinafter JUDICIAL CONFERENCE COMMITTEE REPORT], http://www.uscourts.gov/sites/default/files/2017-09-jcus-report_0.pdf. A discussion of the impropriety of this legislative effort - in substance and process-is beyond the scope of this article. 


\section{A CRITIQUE OF MODERN CLASS ACTION JURISPRUDENCE}

Now more than ever, there is a pressing need for the civil litigation system to function properly as the rule of law is increasingly under siege. The current assault on the Constitutional and civil rights of persons based on race, religion, gender, immigration status and more threatens the very fabric of American society. Greater violence, hate crimes, discrimination and divisive policies will undoubtedly lead to greater litigation, and already have. ${ }^{424}$ The country is at a painful juncture in American history, where its values of equality and justice in a pluralistic society, are arguably tested on the daily.

This crisis point is a good time to recollect the values emanating the modern class action rule's civil rights provision, and recommit to honoring the drafters' intent. Five decades ago, the rule drafters found themselves in a similar chaos, where tectonic societal shifts challenged them to design procedures that would enable "parties to secure the just, speedy, and inexpensive determination of every action and proceeding." 425 The modern class action rule's civil rights provision was one answer to that societal turmoil and a concrete embodiment of how historically marginalized people could seek justice and efficiency in the federal courts. This very same rule remains today and continues to play a critical role in American democracy. ${ }^{426}$

424. See, e.g., Nomi Prins \& Tom Dispatch, The White House as Donald Trump's New Casino, SALON (Sept. 26, 2017, 3:00 AM), https://www.salon.com/2017/09/26/the-white-house-as-donaldtrumps-new-casino_partner/ (explaining how President Trump has "been sued 134 times in federal court since he assumed the presidency").

425. FED. R. CIV. P. 1

426. Brief of Amici Curiae NAACP Legal Defense \& Education Fund, Inc., et. al in Support of Respondents in Nos. 16-285 \& 16-300 and Petitioner in No. 16-307 at 1-7, 19-26, Epic Sys. Corp. v. Lewis, 137 S. Ct. 809 (2017) (Nos. 16-285, 16-300, 16-307), 2017 WL 3588728 (describing importance of collective action to enforce anti-discrimination statutes). The NAACP Legal Defense and Educational Fund, the Impact Fund, and thirty civil rights organization describe the current necessity for collective action in combatting employment discrimination:

Concerted actions are essential to remedying employment discrimination, and much important civil rights jurisprudence has developed in the context of this group paradigm. Individualized actions, by contrast, are poorly equipped to address pervasive and entrenched discrimination. They preclude workers from using three major tools for Id. at 19 .

identifying and remedying workplace discrimination.

In addition to the class action, court-ordered injunctions that apply to non-parties nationwide have gained traction as a means of creating systemic change under both the Obama and Trump administrations. See generally, Samuel L. Bray, Multiple Chancellors: Reforming the National Injunction, 131 HARV. L. REV. 1 (2017). Whether a national injunction is an appropriate alternative to representative litigation is an important issue, which I am grateful to Professor Howard Wasserman for raising. While the issue is beyond the scope of this paper, this timely discussion is starting. Compare Bray, supra, at 4, 60 (arguing for a prohibition of national injunctions and offering the class 
This is not to say that this procedural vehicle is flawless or free from abuse. There are a number of ways in which the rule may be improved, as recognized by recent proposals of the Rule 23 Subcommittee to the Advisory Committee on Civil Rules and related comments, testimony and input provided by the bar, bench and legal academy nationwide. ${ }^{427}$ Tellingly, however, is that the Advisory Committee ultimately chose not to change Rule 23's civil rights class action provision. ${ }^{428}$ The text of the modern class action rule-the fulcrum upon which all federal cases balance - does not necessitate or explain the higher hurdle for civil rights class certification. Rather, it is judicial interpretation of the rule's scriptures that has resulted in the rule's diminished utility. ${ }^{429}$

Despite the pendulum's swing from a heyday of civil rights class actions to a more measured one, class actions are still being brought to enforce all manner of civil rights today. For example, a half dozen Black men and women, Black Lives Matter Chicago, and a number of community organizations recently filed a (b)(2) class action complaint seeking federal court oversight of Chicago City's Police Department, alleging various unconstitutional racially discriminatory policies and practices against thousands of individuals, primarily Black and Latinx. ${ }^{430}$

action as the "obvious answer"); with Suzette M. Malveaux, Response: Class Actions, Civil Rights, and the National Injunction, HARV. L. REV. F. (forthcoming Dec. 2017) (opposing prohibition and flagging problem of sole reliance on the class action).

427. Committee on Rules of Practice and Procedure of the Judicial Conference of the U.S., Preliminary Draft of Proposed AMENDMENTS to the Federal Rules of APPELlate, BANKRuPTCY, Civil, AND CRIMINAl Procedure 193-95 (Aug. 2016) [hereinafter Preliminary DRAFT OF PROPOSED AMENDMENTS], http://www.uscourts.gov/sites/default/files/2016-08preliminary_draft_of_rules_forms_published_for_public_comment_0.pdf; JUDICIAL CONFERENCE

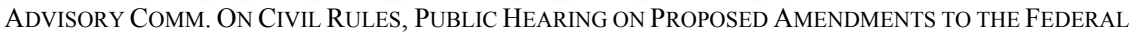
Rules of Civil Procedure Before the Judicial Conference Advisory CommitTeE ON CiviL RULES (Nov. 3, 2016), http://www.uscourts.gov/sites/default/files/written_testimony_for_civil_rules_ hearing 11-3-16 0.pdf; Judicial CONFERENCE AdvisORY COMM. ON Civil RuLES, PubliC HEARING ON PROPOSED AMENDMENTS to the FEDERAl Rules of Civil PROCEDURE BEFORE THE Judicial CONFERENCE ADVISORY COMMITTEE ON CIVIL RUles (Jan. 4, 2017), http://www.uscourts.gov/sites/default/files/2017-01-04-testimony_and_comment_handout.pdf.

428. The proposed amendments ultimately disseminated by the Civil Rules Advisory Committee do not address Rule 23(b)(2)'s treatment of monetary relief or Rule 23(a)'s heightened evidentiary burden for commonality out of deference to the Court's decision in Wal-Mart. JUDICIAL CONFERENCE COMMITTEE REPORT, supra note 423 with PRELIMINARY DRAFT OF PROPOSED AMENDMENTS, supra note 427 , at $218-32$.

429. As discussed, this pendulum continues to swing, and has not yet rested on a clear landing place.

430. See Class Action Complaint at 2-7, 114-20, 127-131, Campbell v. City of Chicago, No. 1:16-CV-04467, 2017 WL 2587483 (N.D. Ill. June 14, 2017); Press Release, MacArthur Justice Center, Landmark Class Action Lawsuit Filed Against the City of Chicago Alleging Racially Discriminatory Policing and Violent Police Abuse (June 14, 2017), http://www.law.northwestern.edu/ legalclinic/macarthur/projects/police/documents/CPD\%20Class\%20Action\%20Press $\% 20$ Release $\% 2$ OFINAL.pdf. 
Another example of a recent (b)(2) class action is one brought by a male and female Army veteran on behalf of hundreds of thousands of veterans since 9/11 who served in Iraq and Afghanistan and developed posttraumatic stress disorder (PTSD) or traumatic brain injury during their service and were allegedly released with less-than-Honorable discharges in violation of the Constitution and Administrative Procedure Act. ${ }^{431}$

In addition to the traditional civil rights injunctive class actions pursued under (b)(2), cases seeking monetary relief for similar alleged violations of federal law are also being pursued under (b)(3). For example, in a case brought on behalf of veterans disabled in combat, the National Veterans Legal Services Program brought a (b)(3) class action against the federal government, alleging that its policy improperly capped retroactive disability payments owed to six years, thereby depriving thousands of veterans their proper benefits. ${ }^{432}$ Most recently, three female employees filed a class action against Google, alleging that it systematically discriminated against women in hiring, pay and promotions, in violation of various local labor laws. ${ }^{433}$ Plaintiffs seek wages due, damages, and injunctive relief, and pursue certification under a California law similar to (b)(3). ${ }^{434}$ Of course, some contemporary class actions have been brought under both (b)(2) and (b)(3). For example, a class action was filed on behalf of impoverished members of the Ferguson, Missouri community against the City for its policy of allegedly using its municipal court and jail to collect fees and fines as a revenue source for the City, functionally operating a debtor's prison system in violation of the Fourteenth Amendment's Due Process clause. ${ }^{435}$

431. See Amended Complaint at 1-3, 25-27, Kennedy v. Speer, No. 3:16-cv-2010-WWE, 2017 WL 4157527 (D. Conn Apr. 17, 2017); Yale Law School, Veterans Clinic Files Nationwide ClassAction Lawsuit on Behalf of Army Veterans, IN THE PRESS (Apr. 17, 2017), https://law.yale.edu/ylstoday/news/veterans-clinic-files-nationwide-class-action-lawsuit-behalf-army-veterans.

432. See Class Action Complaint at 1, 6, 16, Soto v. United States, No. 1:17-cv-00051 (S.D. Tex. Mar. 2, 2017); Press Release, National Veterans Legal Services Program, NVLSP Files Class Action Lawsuit Against Federal Government Over Unlawful Policy Shortchanging Combat-Injured Veterans on Their Disability Benefits (March 2, 2017), http://www.nvlsp.org/news-room/press-releases/nvlspfiles-class-action-lawsuit-against-government-over-shortchanging-comb.

433. Class Action Complaint at 1-3, 6-7, Ellis v. Google, Inc., No. CGC-17-561299, 2017 WL 4075207 (Cal. Super. Sept. 14, 2017); Press Release, Lieff Cabraser Heimann \& Bernstein, LLP, Google Sued in Class Action Alleging Sex Discrimination-Complaint Charges Google With Multiple Pay and Promotion Violations, Illegal Occupational Segregation of Female Employees (Sept. 14, 2017), https://www.lieffcabraser.com/2017/09/google-sued-in-class-action-alleging-sexdiscrimination/; Clare O'Connor, 'One in 100 Million' Chance Alleged Gender Pay Gap at Google is Random, Says Class Action Lawyer, FORBES (Aug. 9, 2017), https://www.forbes.com/sites/ clareoconnor/2017/08/09/one-in-100-million-chance-alleged-gender-pay-gap-at-google-is-randomsays-class-action-lawyer/\#6beb3fb82d52.

434. Id.

435. Class Action Complaint at 1-5, Fant et al. v. City of Ferguson, No. 4L15-CV-00253-AGF, 
Preservation of the civil rights class action is even more critical today in light of the new administration's retraction of systemic pattern or practice cases by executive agencies tasked with enforcement of antidiscrimination statutes. ${ }^{436}$ The private bar will need to fill the void left by such retraction. ${ }^{437}$ There is ample evidence that marginalized people and their advocates are up for the task. Betty Dukes, the named plaintiff in Wal-Mart, is a perfect example of someone with the grit and perseverance that characterizes many who challenge widespread systemic discrimination on behalf of others. Although Ms. Dukes recently passed away, her spirit lives on in others that carry the torch against injustice. At a Senate Judiciary Committee hearing on access to justice issues, and in response to Senator Patrick Leahy's question about whether she would give up after her loss in the Supreme Court's ruling in Wal-Mart, Ms. Dukes said no, "The best is yet to come." 438 Indeed, the future direction of collective action, as suggested by some of the Supreme Court's recent class action jurisprudence, may be on the rise. ${ }^{439}$

\section{CONCLUSION}

At this point, the pendulum has swung away from the heyday of classwide injunctions against systemic discrimination towards a more complex

2017 WL 3392073 (E.D. Mo. Feb. 8, 2015); see also Jenkins et al. v. City of Jennings, No. 4:15-cv00252 (E.D. Mo. Feb. 8, 2015) (similar case brought against the city of Jennings). The suit against the City of Jennings was settled for $\$ 4.7$ million. Stephen S. Hsu, Jennings to pay $\$ 4.7 M$ settlement to those jailed over court debts, ST. LOUIS POST-DisPaTCH (July 14, 2016), http://www.stltoday.com/news/local/metro/jennings-to-pay-m-settlement-to-those-jailed-overcourt/article e0ffdc5c-6996-5cb9-b9db-8d6cbfa9dc0a.html.

436. See e.g., Letter from Candice Jackson, Acting Assistant Sec'y, Office for Civil Rights, U.S. Dep't of Educ., to College and University Presidents (Sept. 22, 2017), https://www2.ed.gov/ about/offices/list/ocr/letters/colleague-title-ix-201709.pdf (withdrawing Title IX guidance on investigating and adjudicating allegations of campus sexual misconduct); Letter from Sandra Battle, Acting Assistant Sec'y, Office for Civil Rights, U.S. Dep't of Educ., and T.E. Wheeler, II, Acting Assistant Attorney Gen. for Civil Rights, U.S. Dep't of Justice, to College and University Presidents (Feb. 22, 2017), http://i2.cdn.turner.com/cnn/2017/images/02/23/1atransletterpdf022317.pdf (withdrawing Title IX guidance on protections for LGBT persons use of sex-segregated facilities); Press Release, Department of Justice, Department of Justice Announces Changes to the Collaborative Reform Initiative (Sept. 15, 2017), https://www.justice.gov/opa/pr/department-justice-announceschanges-collaborative-reform-initiative (withdrawing collaborative reform efforts in policing).

437. See Perry Cooper, Will Civil Rights Class Actions Multiply Under Trump?, BLoOMBERG BNA NEws (Dec. 2, 2016), https://www.bna.com/civil-rights-class-n73014447996/ (Impact Fund Executive Director Jocelyn Larkin, Esq. and Professor Suzette Malveaux describing role of private bar enforcement and class actions in civil rights).

438. Barriers to Justice and Accountability: How the Supreme Court's Recent Rulings Will Affect Corporate Behavior Before the S. Comm. on the Judiciary, 112th Cong. 14 (2011) (statement of Betty Dukes, Lead Plaintiff on Wal-Mart, Inc. v. Dukes), https://www.judiciary.senate.gov/imo/ media/doc/11-6-29\%20Dukes\%20Testimony.pdf.

439. See SEYFARTH SHAW LLP, 2017 REPORT, supra note 274, at 5. 
web of conditions. The modern class action rule's civil rights provision was admittedly born in a simpler time. Fifty years after the modern rule's birth, there has been great expansion in substantive rights and remedies, societal diversity, technological advances and globalization. Although explicit bigotry and hatred still exist—and have found renewed expression as of late - the Jim Crow signs delineating separate facilities for Blacks and Whites and numerous facially discriminatory policies have become relics of the past. In their place, institutional racism and structural barriers, on the one hand, and implicit bias of individuals, ${ }^{440}$ on the other hand, ${ }^{441}$ account for much of the driving force behind group disparities.

Although the specific targets of anti-discrimination litigation may look different, at their core is systemic subordination that Rule 23(b)(2) was designed to address. ${ }^{442}$ The Rule's goal of enabling broad injunctive and declaratory relief appropriate to the class as a whole when countenanced is as salient today as it was a half century ago. Contemporary class action jurisprudence should recommit itself to allowing the procedural rules to function as the drafters intended and enable American values like equality and justice to prevail. Too much is at stake on this golden anniversary.

440. This is true, of course, for discrimination based on other protected classes as well.

441. This, of course, does not suggest that there is not significant explicit bias, which is wellevidenced by the increase in violence and hate crimes by white supremacist organizations. See Mark Potok, The Year in Hate and Extremism, SOUTHERn POVERTY LAW CENTER (Feb. 15, 2017), https://www.splcenter.org/fighting-hate/intelligence-report/2017/year-hate-and-extremism (discussing the increase of people in white nationalist/neo-Nazi groups); see also supra notes 1-3 and accompanying text (discussing a spike in an unprecedented spike in hate crimes, violence and discrimination in modern American history).

442. I.e., formalized segregation and Jim Crow laws. 